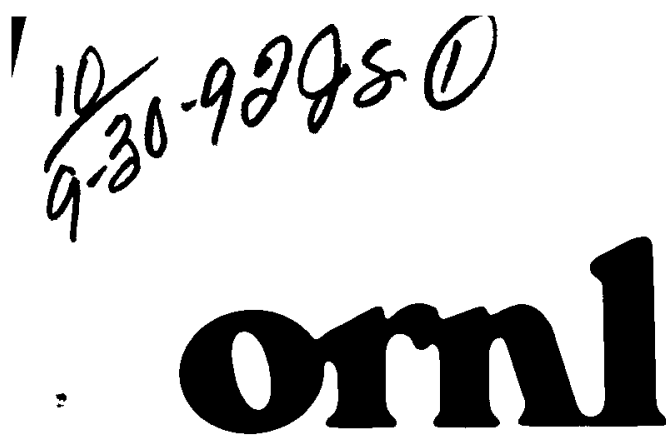

OFNL/SUE--87-07685/2

OAK RIDGE

NATIONAL

LABORATORY

MAGTHW MLARELTLA
Interference of Wedge-Shaped Protrusions On the Faces of a Griffith Crack in Biaxial Stress

Final Report

J. A. M. Boulet

Prepared by

The University of Tennessee

Knoxville, Tennessee 37996-2030

CERAMIC TECHNOLOGY FOR

ADVANCED HEAT ENGINES

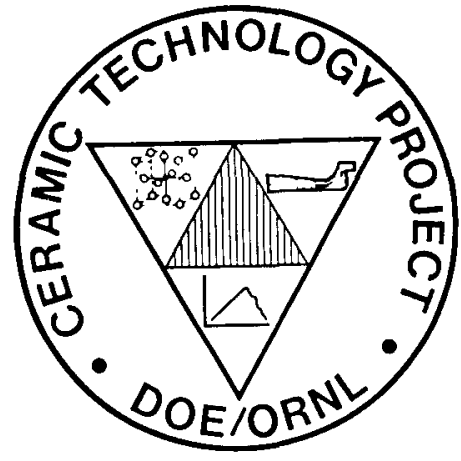

\section{MANAGED BY}

MARTIN MARIETTA ENERGY SYSTEMS, INC.

FOR THE UNITED STATES

DEPARTMENT OF ENERGY

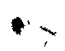

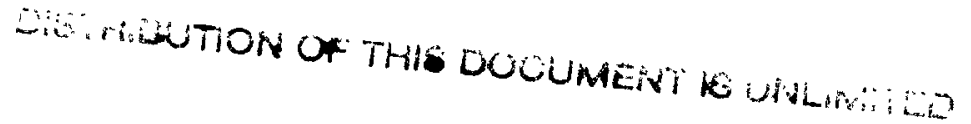


This report has been reproduced directly from the best available copy.

Available to DOE and DOE contractors from the Office of Scientific and Technical Information, P.O. Box 62, Oak Ridge, TN 37831; prices available from (615) 576-8401, FTS 626-8401.

Available to the public from the National Technical Information Service, U.S. Department of Commerce, 5285 Port Royal Rd., Springfield, VA 22161.

This report was prepared as an account of work sponsored by an agency of the United States Government. Neither the United States Government nor any agency thereof, nor any of their employees, makes any warranty, express or implied, or assumes any legal liability or responsibility for the accuracy, completeness, or usefulness of any information, apparatus, product, or process disclosed, or represents that its use would not infringe privately owned rights. Reference herein to any specific commercial product, process, or service by trade name, trademark, manufacturer, or otherwise, does not necessarily constitute or imply its endorsement, recommendation, or favoring by the United States Government or any agency thereof. The views and opinions of authors expressed herein do not necessarily state or reftect those of the United States Government or any agency thereof. 


\section{DISCLAIMER}

This report was prepared as an account of work sponsored by an agency of the United States Government. Neither the United States Government nor any agency Thereof, nor any of their employees, makes any warranty, express or implied, or assumes any legal liability or responsibility for the accuracy, completeness, or usefulness of any information, apparatus, product, or process disclosed, or represents that its use would not infringe privately owned rights. Reference herein to any specific commercial product, process, or service by trade name, trademark, manufacturer, or otherwise does not necessarily constitute or imply its endorsement, recommendation, or favoring by the United States Government or any agency thereof. The views and opinions of authors expressed herein do not necessarily state or reflect those of the United States Government or any agency thereof. 


\section{DISCLAIMER}

Portions of this document may be illegible in electronic image products. Images are produced from the best available original document. 


\title{
INTERFERENCE OF WEDGE-SHAPED PROTRUSIONS \\ ON THE FACES OF A GRIFFITH CRACK IN BIAXIAL STRESS
}

\author{
J. A. M. Boulet
}

Date Published-April 1992

\section{FINAL REPORT}

Prepared by

The University of Tennessee

Knoxville, Tennessee 37996-2030

Subcontract No. 41B-07685C-782

\author{
Funded by \\ Office of Transportation Materials \\ Office of Transportation Technologies \\ the Assistant Secretary for Conservation and Renewable Energy \\ U.S. Department of Energy \\ EE 5101000
}

\author{
for \\ OAK RIDGE NATIONAL LABORATORY \\ Oak Ridge, Tennessee 37831 \\ managed by \\ MARTIN MARIETTA ENERGY SYSTEMS, INC. \\ for the \\ U.S. DEPARTMENT OF ENERGY \\ under Contract DE-AC05-84OR21400
}

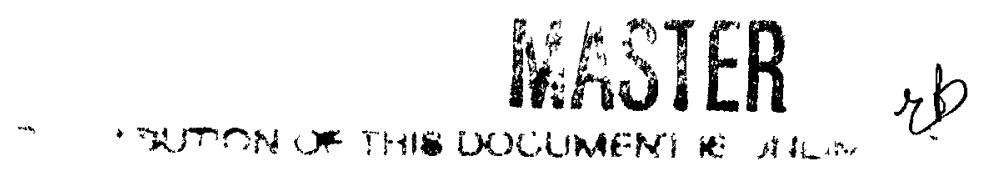


TABLE OF CONTENTS

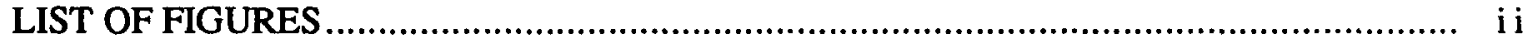

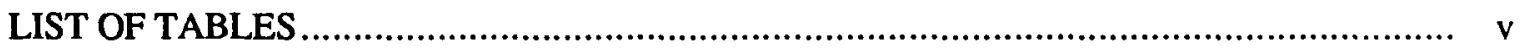

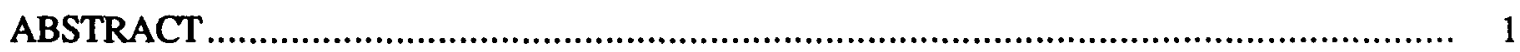

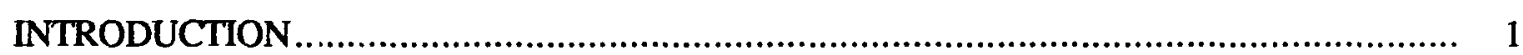

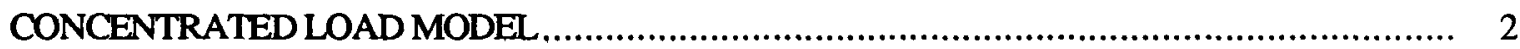

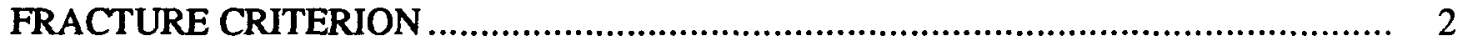

PROTRUSION INTERFERENCE IN SHEAR ......................................................... 3

FRACTURE CRITERION ............................................................................ 5

COMPATIBILITY CONDITION................................................................ 8

SOLUTION FOR PROBLEM A....................................................................... 9

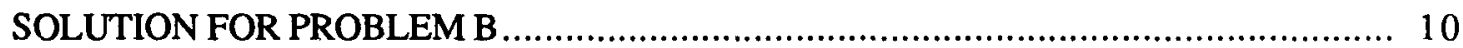

CONDITIONS FOR INTERFERENCE TO OCCUR ........................................... 12

CONDITIONS FOR INTERFERENCE TO INFLUENCE FRACTURE........................... 15

ACCURACY OF CONCENTRATED LOAD MODEL ............................................. 17

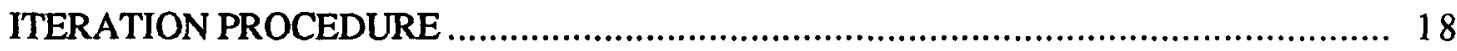

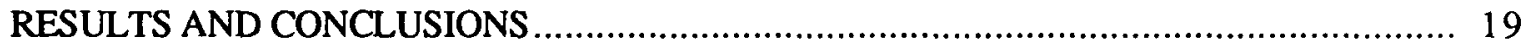

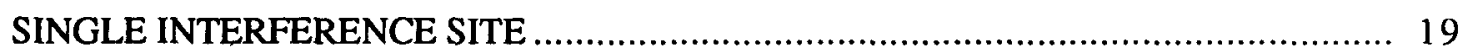

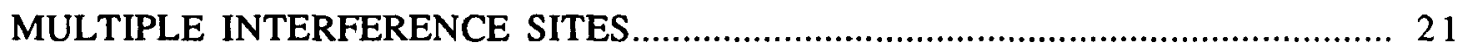

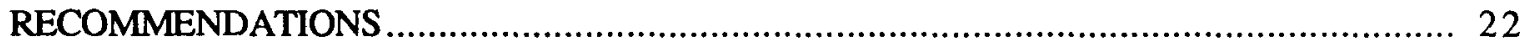

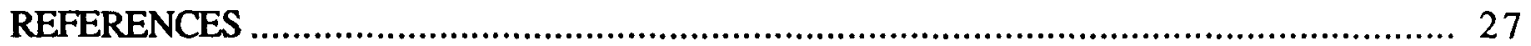




\section{LIST OF FIGURES}

Figure Caption Page

1 Griffith Crack Subjected Simultaneously to Arbitrarily Oriented Biaxial Stress at Infinity and Concentrated Loads Representing Interaction at $x=b$. The angle $\beta$ is referred to later as the stress orientation angle.

2 Interference Between Wedge-Shaped Bumps on the Faces of a Griffith Crack.

Exaggerated Bending of Wedge-Shaped Protrusions During Interference Due to Relative Shear Displacement of Crack Faces.

Problem B: Concentrated Normal Force, P, Applied to One Side of a Wedge-Shaped Bump on a Half-Plane.

Concentrated Loads Statically Equivalent to the Stresses on the Line $y=h,|x|<h \tan \alpha$ in Fig. 4. These are the loads applied at $x=b$ in Figure 1 .

Regions in Which the Various Stress Cases Produce Interference. The curved lines are the quantity $\phi$ defined in (46). The lines $\beta=0$ and $\beta=\beta^{*}$ are asymptotes $\left(\beta^{*}=\alpha-90^{\circ}\right)$. Between them, $\phi>1$. The region labels follow from (46) and Tables 1 and 2 . For each stress case, the ratio of the labeled area to $\pi$ [the area corresponding to all possible points $(\rho, \beta)$ for one case] is a measure of the likelihood that interference will occur. Thus, for the value of $\alpha$ used here $(\tan \alpha=1 / 2)$, the likelihood of having interference is much greater for biaxial compression (case IV) than it is for biaxial tension (case I).

Dependence of Boundary between Stress Cases I and IV on Wedge Half-Angle, $\alpha$. The region below the curve is stress case I, and that above the curve is case IV [see (46), Table 2, and Fig. 6]. As $\alpha$ decreases (wedge sharpens), the region in which biaxial tension (case I) produces interference grows, while that in which biaxial compression (case IV) produces interference shrinks. 


\section{LIST OF FIGURES}

Figure Caption

Page

1 Griffith Crack Subjected Simultaneously to Arbitrarily Oriented Biaxial Stress at Infinity and Concentrated Loads Representing Interaction at $x=b$. The angle $\beta$ is referred to later as the stress orientation angle.

2 Interference Between Wedge-Shaped Bumps on the Faces of a Griffith Crack.

Exaggerated Bending of Wedge-Shaped Protrusions During Interference Due to Relative Shear Displacement of Crack Faces.

Problem B: Concentrated Normal Force, P, Applied to One Side of a Wedge-Shaped Bump on a Half-Plane.

Concentrated Loads Statically Equivalent to the Stresses on the Line $y=h,|x|<h \tan \alpha$ in Fig. 4. These are the loads applied at $x=b$ in Figure 1 .

6 Regions in Which the Various Stress Cases Produce Interference. The curved lines are the quantity $\phi$ defined in (46). The lines $\beta=0$ and $\beta=\beta^{*}$ are asymptotes $\left(\beta^{*}=\alpha-90^{\circ}\right)$. Between them, $\phi>1$. The region labels follow from (46) and Tables 1 and 2 . For each stress case, the ratio of the labeled area to $\pi$ [the area corresponding to all possible points $(\rho, \beta)$ for one case] is a measure of the likelihood that interference will occur. Thus, for the value of $\alpha$ used here $(\tan \alpha=1 / 2)$, the likelihood of having interference is much greater for biaxial compression (case IV) than it is for biaxial tension (case I).

Dependence of Boundary between Stress Cases I and IV on Wedge Half-Angle, $\alpha$. The region below the curve is stress case 1 , and that above the curve is case IV [see (46), Table 2, and Fig. 6]. As $\alpha$ decreases (wedge sharpens), the region in which biaxial tension (case I) produces interference grows, while that in which biaxial compression (case IV) produces interference shrinks. 
8 Dependence of the Required Fracture Toughness Ratio on the Wedge Half-Angle, $\alpha$. The ordinate, $R$, is the ratio of the fracture toughness required when interference is absent to that required when interference is present. The interference site is located at the center of the crack. Narrower wedges have steeper sides, and so present more of a barrier to relative shear displacement than do broader wedges. For a given wedge, increasing the applied stress moves the contact force closer to the apex, where the wedge is more flexible. Thus, the contact force generated by a given relative shear displacement, and so the significance of interference, decreases. From (46), Table 1 , and the value of $\rho$ and $\beta$, interference occurs only for $\alpha<26.6^{\circ}$

9 Dependence of the Required Fracture Toughness Ratio on Orientation of the Applied Stress. The interference site is located at the center of the crack. In the absence of interference, the relative shear displacement of the crack faces is maximum for $\beta=45^{\circ}+\alpha / 2 \quad\left(\beta=52.5^{\circ}\right)$. Hence, the influence of interference increases as $\beta$ approaches this value.

10 Dependence of the Required Fracture Toughness Ratio on the Stress Ratio, $\rho$. Both stresses are tensile. The interference site is located at the center of the crack. Because the relative shear displacements produced by the two principal stresses oppose each other, increasing the stress ratio reduces interference.

11 Dependence of the Required Fracture Toughness Ratio on Poisson's Ratio. The interference site is located at the center of the crack. Variation of Poisson's ratio within realistic limits has little influence on the amount of interference.

12 Dependence of the Required Fracture Toughness Ratio on Wedge Size. The interference site is located at the center of the crack. As the wedge height increases, so does the interference.

13 Dependence of the Required Fracture Toughness Ratio (at $x=a)$ on the Location of the Interference Site. As the interference site approaches the crack tip, the influence of the interference on the fracture toughness required at the crack tip increases. 
Figure Caption

14 Influence of Number of Interference Sites on Required Fracture Toughness. Applied (remote) stress is that which, in the absence of interference, opens the crack center a distance equal to five per cent of the wedge height $(\Delta v / h)=0.05$ at $x=0)$. As the number of sites increases, so does the influence on required fracture toughness. The smaller the wedge height relative to the crack length, the less the influence of the interference.

15 Required Separation of Interference Sites. As the crack opens, the contact load moves up the wedge face. This increases the distance on either side of the wedge at which the approximation of the present model becomes inaccurate. 


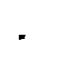


$\begin{array}{lll}\text { Table Caption } & \text { Page }\end{array}$

1 Restrictions on Stress Ratio. If these are not satisfied, interference does not occur. The quantity $\phi$ is defined in (46).

2 Stress Cases. The four possible combinations of tensile and compressive principal stress are labeled in the rightmost column.

3 Intervals of Unrestricted Stress Ratio. In these intervals, every value of the stress ratio, $\rho$, produces interference.

4 Critical Crack Length. For cracks smaller than $a_{c}$, the presence of interference alters the fracture stress. Data in the first three columns are from the literature ${ }^{12}$. Values of $a_{c}$ are computed from (57). 


\title{
INTERFERENCE OF WEDGE-SHAPED PROTRUSIONS ON THE FACES OF A GRIFFITH CRACK IN BIAXIAL STRESS
}

\author{
J. A. M. Boulet
}

\begin{abstract}
An initial investigation of the influence of protrusion interference on the fracture toughness required to prevent unstable propagation of a Griffith crack in a brittle material is described. The interference is caused by relative shear displacement of the crack faces when subjected to remote biaxial stress with neither principal stress parallel to the crack. It is shown that for room temperature cracks smaller than about one centimeter in silicon carbide, or about one millimeter in silicon nitride, the presence of interference changes the fracture stress. A mathematical model based on linear elasticity solutions and including multiple interference sites at arbitrarily specified positions on the crack is presented. Computations of the change in required fracture toughness and its dependence on wedge geometry (size and vertex angle), applied stresses (orientation and magnitude), and location of the interference site are discussed. Results indicate that a single interference site has only a slight effect on required toughness. However, the influence of interference increases monotonically with the number of interference sites. The two-dimensional model described herein is not accurate when the interference sites are closely spaced.
\end{abstract}

\section{INTRODUCTION}

When a Griffith (line) crack is subjected to arbitrarily oriented principal stresses applied at infinity, the stress intensity factors at the crack tips (ends) may be combined in any of several fracture criteria to predict the fracture stress (the level of applied stress required to initiate unstable crack propagation). In the classical analysis of this problem ${ }^{1}$, the crack faces do not interact with each other. But for real cracks, various kinds of mechanical crack-face interaction can occur. Under compressive stresses, contact of the faces can produce pressure along the entire crack. Under biaxial tension with the crack not parallel to either principal direction, relative shear displacement of the faces can cause the protrusions on rough faces to interfere with each other, and so generate interaction forces. For fibrous composites, fibers that bridge the crack can mediate interaction between the faces. Any crack-face interaction changes the stress intensity factors from what they would be if the interaction were not present. Consequently, the predicted fracture stress and the fracture toughness required to avoid unstable crack propagation are changed. The amount of change is a direct measure of the importance of any kind of crack-face interaction.

Research sponsored by the U.S. Department of Energy, Assistant Secretary for Conservation and Renewable Energy, Office of Transportation Technologies, as part of the Ceramic Technology Project of the Advanced Materials Development Program, under contract DE-AC05-84OR21400 with Martin Marietta Energy Systems, Inc. 


\section{CONCENTRATED LOAD MODEL}

The problem considered herein is that of predicting the initiation of unstable propagation of a Griffith crack subjected to arbitrary biaxial stress at infinity, with crack-face interaction represented by concentrated loads. The use of concentrated loads is appropriate when interaction takes place in regions very small relative to the crack size.

Concentrated loads are not the only reasonable model for crack-face interaction. Another approach to this problem has recently been reported in several investigations of fracture in ceramic composites ${ }^{2-4}$. There, interaction is modeled as traction distributed continuously over some region of the crack faces. The latter model admits a Green's function formulation that leads to a nonlinear integral (or differential) equation. With the former model, as described below, the Green's function formalism is unnecessary and the governing equations lead directly to a set of simultaneous, nonlinear algebraic equations. Thus, the concentrated loads model leads to the simpler computational problem.

The concentrated loads representing interaction of crack faces must be found before their influence on crack propagation can be assessed. This can be done with an iteration scheme based on compatibility of displacements for two problems, referred to hereafter as problems $A$ and $B$, in the linear theory of elasticity. (The assumption of linearity is appropriate for analysis of brittle fracture.) Problem $A$ is a line crack subjected simultaneously to arbitrarily oriented biaxial stress at infinity and concentrated loads on the crack faces. Problem B is a half-plane with interaction sites on the boundary subjected to concentrated loads statically equivalent to those used in problem $A$. From the solution to each problem one can compute the displacement of the upper crack face relative to that of the lower crack face. The correct set of interaction loads gives equal (compatible) relative displacements for both problems. We assume that the set of interaction forces that gives compatible displacements is unique.

\section{FRACTURE CRITERION}

Once interaction loads are found, their effect on crack propagation can be evaluated using any of various fracture criteria. For our initial investigation, we choose the Griffith fracture criterion for biaxial stress written in terms of stress intensity factors $5-6$

$$
\mathrm{K}_{\mathrm{I}}^{2}+\mathrm{K}_{\mathrm{II}}^{2}=\mathrm{K}_{\mathrm{IC}}^{2}
$$

Using the crack half-length, $a$, and the material's shear modulus, $\mu$, we define the following normalized versions of the quantities in (1).

$$
K_{I}^{*}=\frac{K_{I}}{\mu \sqrt{\pi a}}
$$




$$
\begin{aligned}
& K_{I I}^{*}=\frac{K_{I I}}{\mu \sqrt{\pi a}} \\
& K_{I C}^{*}=\frac{K_{I C}}{\mu \sqrt{\pi a}}
\end{aligned}
$$

We also define the normalized applied stress as

$$
\sigma^{*}=\frac{\sigma_{1}}{\mu}
$$

and the biaxial stress ratio as

$$
\rho=\frac{\sigma_{2}}{\sigma_{1}}
$$

where $\sigma_{1}$ and $\sigma_{2}$ are, respectively, the larger and smaller principal stresses at infinity.

\section{PROTRUSION INTERFERENCE IN SHEAR}

As indicated above, problem $A$ is that of a line (Griffith) crack subjected to remote biaxial stress and crack-face interaction loads. Depending on their signs and orientation, the applied stresses tend either to open or to close the crack. Also, when the crack is aligned with neither stress, the stresses tend to shear the crack (slide the opposing faces parallel to themselves, but in opposite directions). Unless the crack is opened enough so that protrusions on the opposing faces are not interleaved, shearing may cause the protrusions to interfere with each other. The specific kind of interaction we examine herein is the interference of protrusions on crack faces during relative shear displacement of the faces.

For our initial investigation, we suppose that the crack is opened enough so that the faces are in contact at only one point (the site of the tallest bumps) and that the interference site is small compared with the crack size. Problem A is then represented by Figure 1, where the interference site is shown at $x=b$. (For multiple interference sites, Figure 1 would show concentrated loads at several locations.) We also assume that the protrusions are wedge-shaped. The wedge geometry is chosen for mathematical convenience rather than for realism. (A more realistic geometry is discussed at the end of this report.) Our model of the interference region is pictured in Figure 2.

When protrusions on opposing crack faces come into contact with each other, they deform elastically. For wedge-shaped bumps, the deformation is essentially bending, as is illustrated qualitatively in Figure 3 . Consequently, contact occurs over a finite region, the contact patch, whose size is small relative to other dimensions of the problem. In general, the contact 


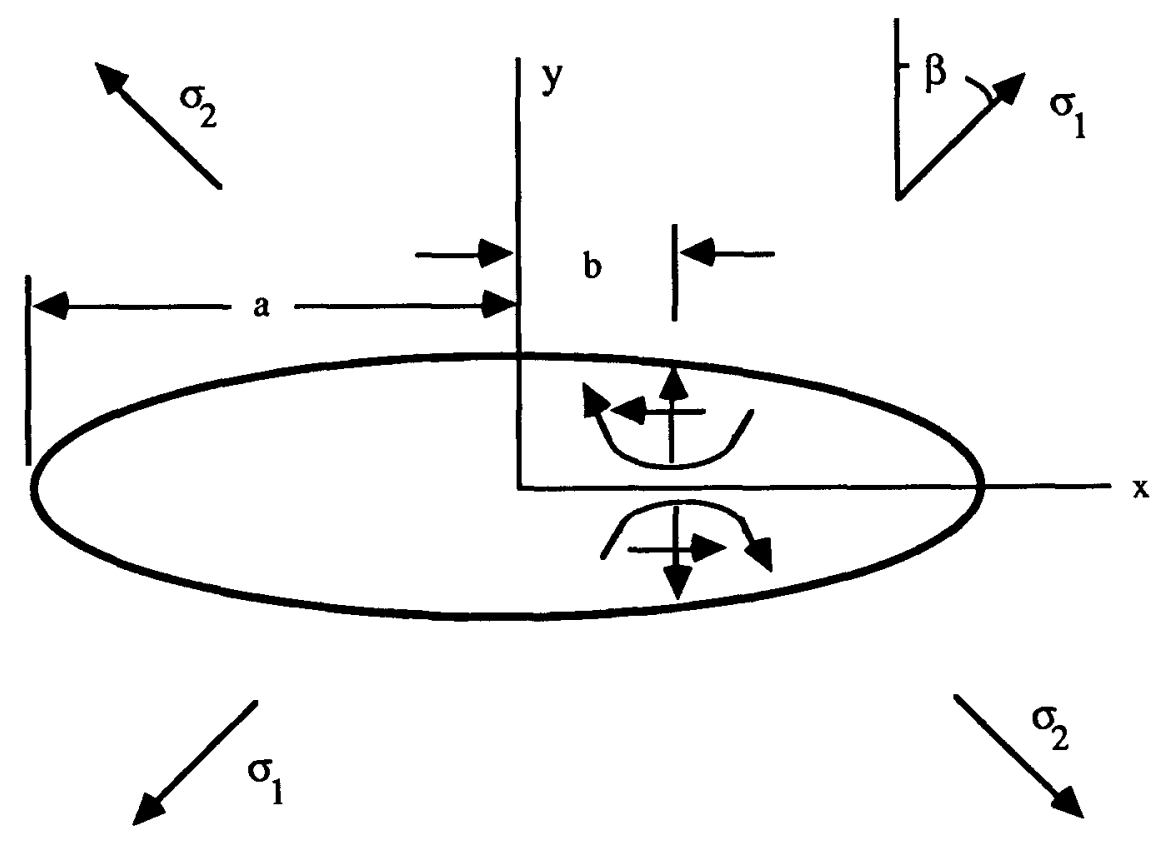

Figure 1. Griffith Crack Subjected Simultaneously to Arbitrarily Oriented Biaxial Stress at Infinity and Concentrated Loads Representing Interaction at $x=b$. The angle $\beta$ is referred to later as the stress orientation angle.

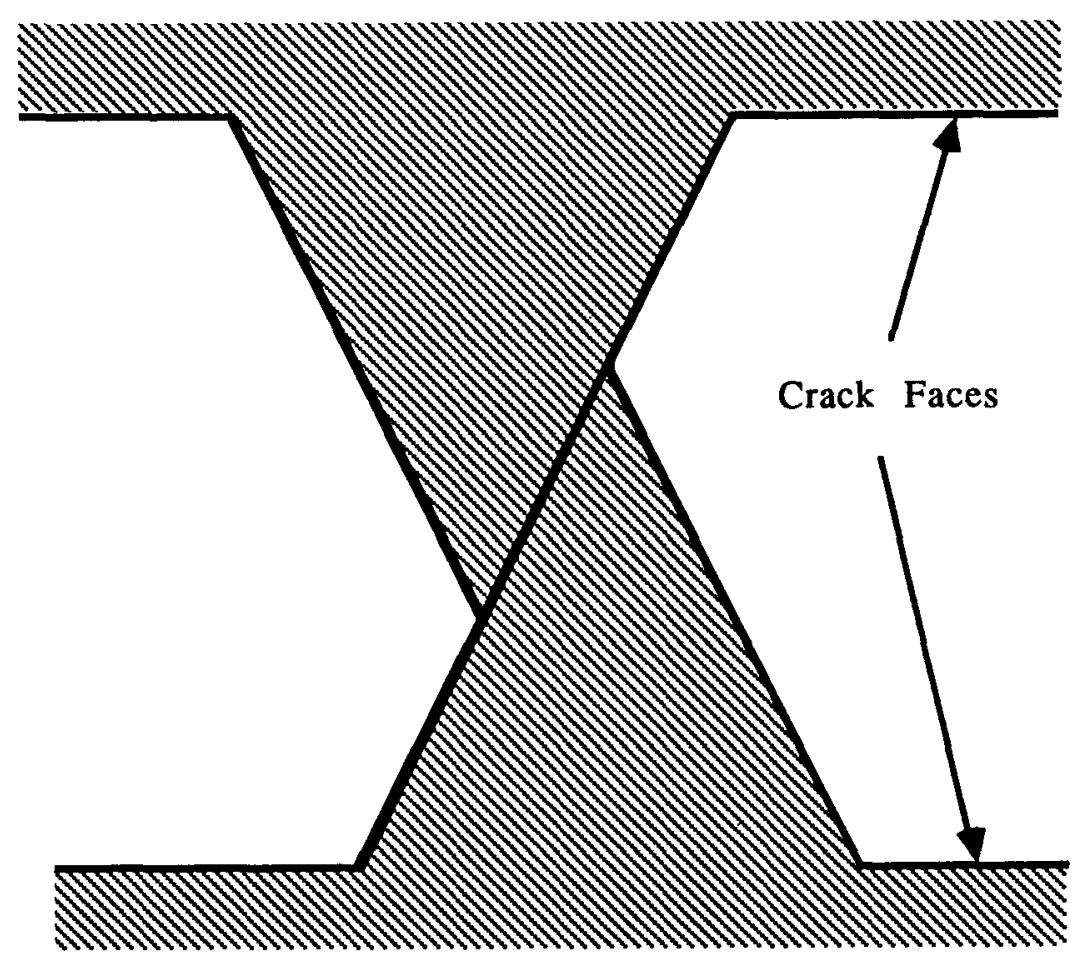

Figure 2. Interference Between Wedge-Shaped Bumps on the Faces of a Griffith Crack. 


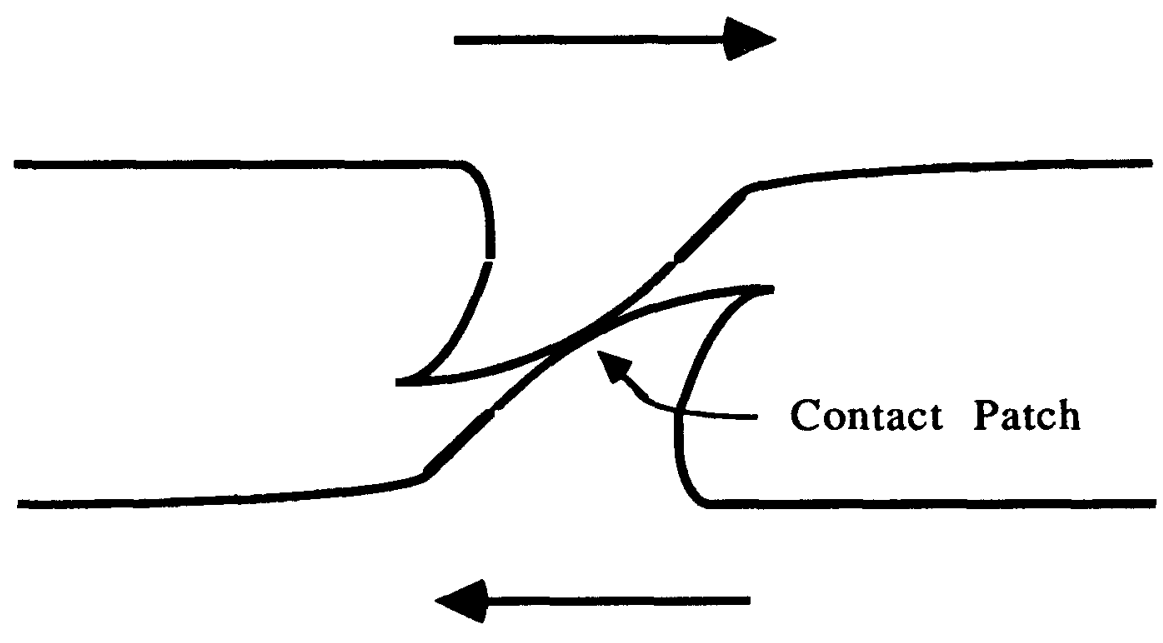

Figure 3. Exaggerated Bending of Wedge-Shaped Protrusions During Interference Due to Relative Shear Displacement of Crack Faces.

pressure is not uniform over the patch. Analysis of the problem is greatly simplified if we assume that the contact patch is essentially a point, so that the pressure distributed over the patch is replaced by a point load (concentrated force per unit length normal to the $x y$ plane), $P$, as shown in Figure 4. Except for a small region in the immediate vicinity of the point where the force is applied, the stress field associated with this simpler problem will be the same as that for the more realistic problem. The difference near the force is not important for the present study, because the stresses that produce fracture are those at the crack tip, which is outside the wedge. Thus, as illustrated in Figure 4, problem B is a half-plane with a wedgeshaped bump on the boundary subjected to a concentrated force normal to one face of the wedge.

As mentioned above, we assume that the interference region is much smaller than the crack. Far from this region, the effect of the interference is the same as if the wedges were represented by the concentrated loads shown in Figure 5. These are the concentrated loads that appear in problem $A$ at $x=b$ (Figure 1).

\section{FRACTURE CRITERION}

Let the number of interference sites be " $n$ ". We define the normalized contact forces at the sites as

$$
P_{i}^{*}=\frac{P_{i}}{\mu a}, i=1,2, \ldots, n
$$




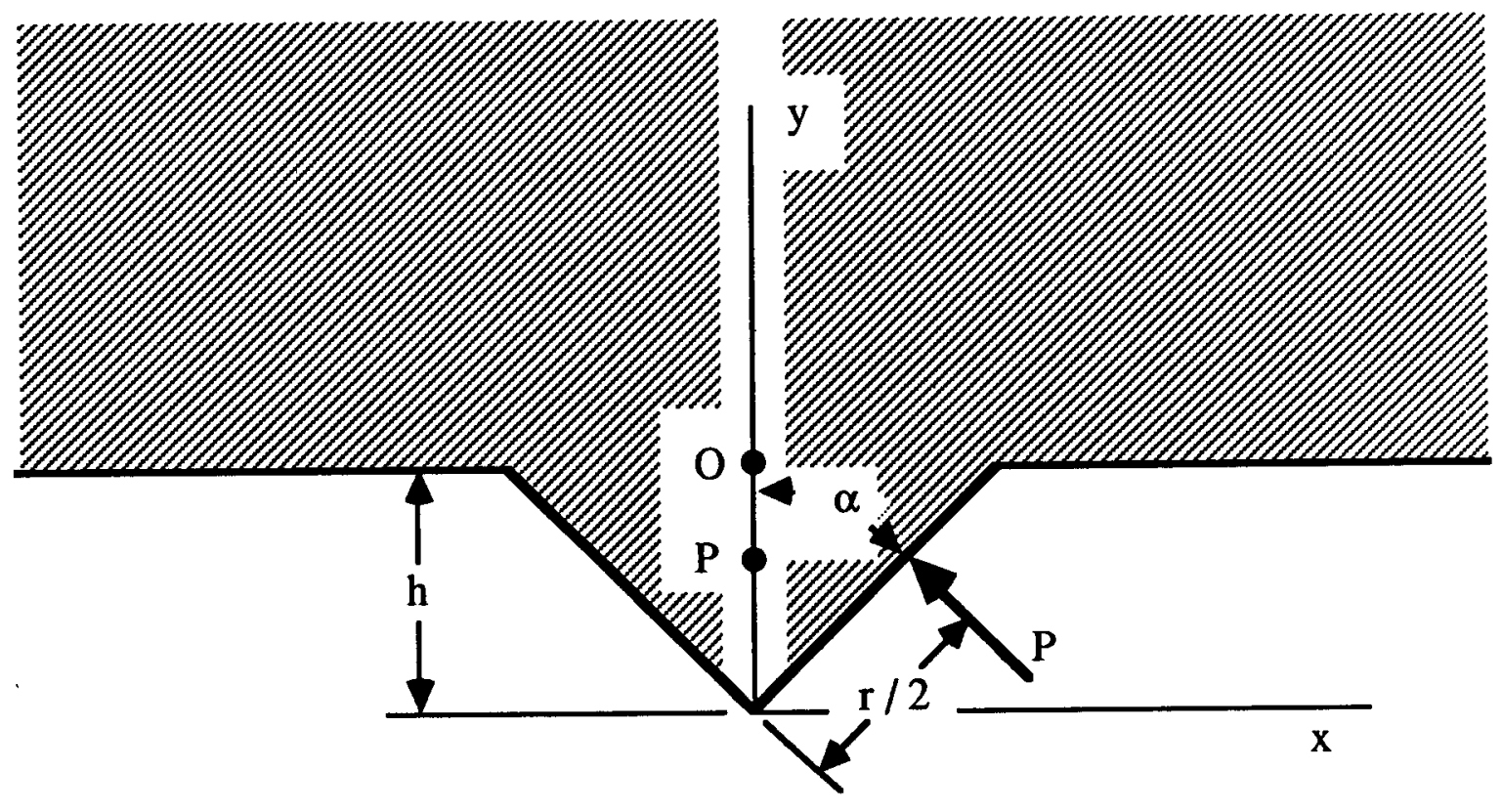

Figure 4. Problem B: Concentrated Normal Force, P, Applied to One Side of a WedgeShaped Bump on a Half-Plane.

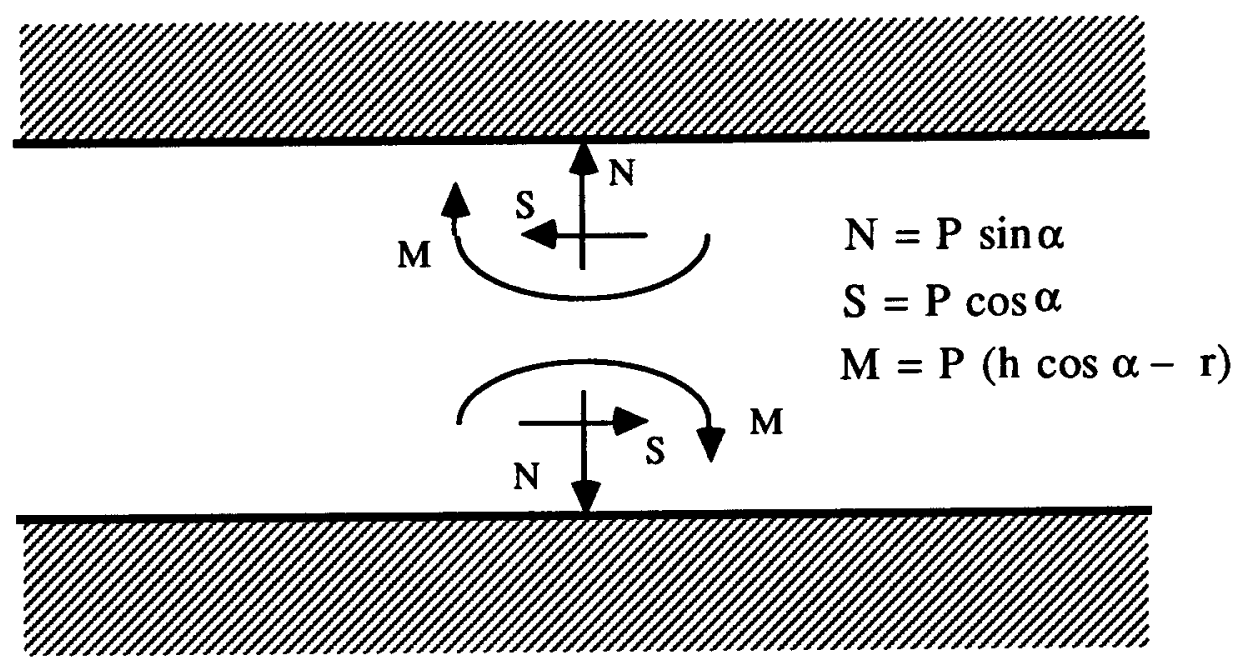

Figure 5. Concentrated Loads Statically Equivalent to the Stresses on the Line $y=h$, $|x|<h \tan \alpha$ in Fig. 4. These are the loads applied at $x=b$ in Figure 1 . 
where $P_{i}$ is the contact force at site "i." When the contact force is present, the stress intensity factors for the right-hand crack tip $(x=a)$ can be derived from published results $7-8$. They are

$$
\begin{gathered}
\mathrm{K}_{\mathrm{I}}^{*}=\left(\mathrm{K}_{\mathrm{I}}^{*}\right)_{0}\left(1+\Delta_{\mathrm{I}}\right) \\
\mathrm{K}_{\mathrm{II}}^{*}=\left(\mathrm{K}_{\mathrm{II}}^{*}\right)_{0}\left(1-\Delta_{\text {II }}\right)
\end{gathered}
$$

where

$$
\begin{gathered}
\left(\mathrm{K}_{\mathrm{I}}^{*}\right)_{0}=\mathrm{D}_{\mathrm{I}} \sigma^{*} \\
\left(\mathrm{~K}_{\mathrm{II}}^{*}\right)_{0}=\mathrm{D}_{\mathrm{II}} \sigma^{*} \\
\mathrm{D}_{\mathrm{I}}=\cos ^{2} \beta+\rho \sin ^{2} \beta \\
\mathrm{D}_{\mathrm{II}}=(1+\rho) \sin \beta \cos \beta \\
\Delta_{\mathrm{I}}=\frac{\sin \alpha_{\mathrm{i}}}{\pi \mathrm{D}_{\mathrm{I}}} \sum_{\mathrm{i}=1}^{\mathrm{n}} \sqrt{\frac{1+\mathrm{S}_{\mathrm{i}}}{1-\mathrm{S}_{\mathrm{i}}}} \frac{\mathrm{P}_{\mathrm{i}}^{*}}{\sigma^{*}} \\
\Delta_{\mathrm{II}}=\frac{\sin \alpha_{\mathrm{i}}}{\pi \mathrm{D}_{\mathrm{II}}} \sum_{\mathrm{i}=1}^{\mathrm{n}} \sqrt{\frac{1+S_{\mathrm{i}}}{1-\mathrm{S}_{\mathrm{i}}}} \frac{\mathrm{P}_{\mathrm{i}}^{*}}{\sigma^{*}} \\
\mathrm{~S}_{\mathrm{i}}=\frac{\mathrm{b}_{\mathrm{i}}}{\mathrm{a}}
\end{gathered}
$$

where the stress ratio, $\rho$, is defined in (6), the stress orientation angle, $\beta$, is defined in Figure 1, and $\alpha_{i}$ (Figure 4) and $b_{i}$ (Figure 1) are the wedge halfangle and position for site "i." Equations for the left-hand crack tip $(x=-a)$ are very similar to those shown here. Thus, the fracture criterion of (1) gives

$$
\sigma_{\mathrm{F}}^{*} \mathrm{f}\left(\sigma_{\mathrm{F}}^{*}\right)=\mathrm{K}_{\mathrm{IC}}^{*}
$$




$$
\mathrm{f}\left(\sigma^{*}\right)=\sqrt{\left[\mathrm{D}_{\mathrm{I}}\left(1+\Delta_{\mathrm{I}}\right)\right]^{2}+\left[\mathrm{D}_{\mathrm{II}}\left(1-\Delta_{\mathrm{II}}\right)\right]^{2}}
$$

In the absence of contact, this reduces to

$$
\begin{gathered}
\sigma_{0}^{*} \mathrm{f}_{0}=\mathrm{K}_{\mathrm{IC}}^{*} \\
\mathrm{f}_{0}=\sqrt{\mathrm{D}_{\mathrm{I}}^{2}+\mathrm{D}_{\mathrm{II}}^{2}}
\end{gathered}
$$

A convenient measure of the significance of the interference is

$$
R=\frac{f_{0}}{f\left(\sigma^{*}\right)}
$$

Physically, $\mathrm{R}$ is (for given applied stresses, crack size, wedge geometry, and wedge location) the ratio of the fracture toughness required in the absence of interference to the fracture toughness required in the presence of interference.

\section{COMPATIBILITY CONDITION}

As discussed previously, the correct values of $\mathrm{P}^{*} \mathrm{i}$ are those that give compatible displacements for problems $\mathrm{A}$ and $\mathrm{B}$ at all sites. To find these, we must first establish the compatibility condition precisely. Let us define displacements $u$ and $v$ in the $x$ and $y$ directions, respectively (Figures 1 and 4). Displacements of the upper crack face relative to those of the lower crack face are

$$
\begin{aligned}
& \Delta u=\left(u_{y=0^{+}}\right)-\left(u_{y}=0^{-}\right) \\
& \Delta v=\left(v_{y}=0^{+}\right)-\left(v_{y}=0^{-}\right)
\end{aligned}
$$

For these relative displacements to exist in problem $A$, the wedge bending displacement shown in Figure 3 must be (see Figures 2 and 4)

$$
\delta_{\mathrm{A}}=\Delta \mathrm{u}-\Delta \mathrm{v} \tan \alpha
$$

For problem B (Figure 4), we take the wedge bending to be the difference between the centerline $x$-direction displacements at the $y$ coordinate of the contact force and at the base of the wedge $(y=h)$. Hence, we have 


$$
\delta_{B}=2\left(u_{P}-u_{O}\right)
$$

For compatibility, $\mathbf{P}_{\mathbf{i}}^{*}$ must be such that at each pair of wedges

$$
\delta_{A}^{*}=\delta_{B}^{*}
$$

where the asterisk denotes dimensionless displacements normalized with respect to the crack half-length. To apply this condition, we must evaluate $\delta_{A}{ }_{A}$ at some point in the immediate vicinity of the concentrated loads representing the wedges. We choose to do so at

$$
x_{i}=b_{i}+h \tan \alpha_{i}, \quad i=1,2, \ldots, n
$$

which is as close to the wedges as possible without being inside them. (It would be inappropriate to evaluate $\delta_{A}^{*}$ inside the "point" where the concentrated loads act. Furthermore, $\delta_{A}^{*}$ is singular at that point.)

Before imposing the compatibility condition, (26), we must relate the contact force to the displacements in problems A and B. These relationships follow from elasticity solutions for the two problems.

\section{SOLUTION FOR PROBLEM A}

A solution for problem A can be constructed by superimposing solutions available from the literature for biaxial stress at infinity ${ }^{9}$ and for concentrated loads on the crack faces ${ }^{7}$. From these solutions, (27), and careful consideration of the limiting values obtained when approaching the crack from above or below, we find the load-displacement relationship at site " $i$ " to be

$$
\delta_{A}^{*}=A_{1}-\sum_{j=1}^{n} A_{2 j} P_{j}^{*}
$$

where

$$
\begin{gathered}
A_{1}=\left(C_{1}-C_{2} \tan \alpha_{i}\right) \sigma^{*} \\
A_{2 j}=C_{3 j}\left(\cos \alpha_{j}+\sin \alpha_{j} \tan \alpha_{i}\right)
\end{gathered}
$$




$$
\begin{gathered}
C_{1}=\frac{1}{2}(K+1)(1-\rho) \sin \beta \cos \beta \sqrt{1-\left(S_{i}+Q\right)^{2}} \\
C_{2}=\frac{1}{2}(\kappa+1) D_{I} \sqrt{1-\left(S_{i}+Q\right)^{2}} \\
C_{3 j}=\frac{K+1}{4 \pi} \ln \left\{\frac{1-S_{j}\left(S_{i}+Q\right)+\sqrt{\left(1-S_{j}^{2}\right)\left[1-\left(S_{i}+Q\right)^{2}\right]}}{1-S_{j}\left(S_{i}+Q\right)-\sqrt{\left(1-S_{j}^{2}\right)\left[1-\left(S_{i}+Q\right)^{2}\right.}}\right\} \\
Q=\frac{h_{i}}{a} \tan \alpha_{i} \\
\kappa=\left\{\begin{array}{l}
3-4 v, \text { plane strain } \\
\frac{3-v}{1+v}, \text { plane stress }
\end{array}\right.
\end{gathered}
$$

\section{SOLUTION FOR PROBLEM B}

No solution to problem $B$ is available from the literature. Equations presented herein for problem $B$ are based on an original solution soon to be submitted for publication. We base our solution on the well-known complex variable formulation of the equations of elasticity9-11. We first map the half-plane with a wedge bump to a half-plane using a degenerate SchwarzChristoffel transformation with only three vertices not at infinity. Then we continue the (as yet unknown) Goursat potential functions analytically across the portions of the boundary on which no resultant force acts, and so produce a Hilbert problem that can easily be solved for the Goursat potential functions. From these functions, we can calculate the displacements for problem $B$. On the centerline, the normalized displacement in the $x$ direction at site " $\mathrm{i}$ " is

$$
u^{*}(\eta)=-P_{i}^{*} F(\eta)
$$

where 


$$
\begin{aligned}
& F(\eta)=\frac{1}{4 \pi}\left\{\frac{2 A(\alpha, \eta)\left(\xi_{P} \sin \alpha_{i}-\eta \cos \alpha_{i}\right)}{\left(\xi_{P}^{2}+\eta^{2}\right)\left(\frac{1+\eta^{2}}{\eta^{2}}\right)^{\gamma}}\right. \\
& \left.-\sin \alpha_{i}(\kappa-1)\left[\pi-\tan ^{-1}\left(\frac{\eta}{\xi_{P}}\right)\right]-\frac{1}{2} \cos \alpha_{i}(\kappa+1) \ln \left(\xi_{P}^{2}+\eta^{2}\right)\right\} \\
& A\left(\alpha_{i}, \eta\right)=\int_{0}^{\eta}\left(\frac{1+s^{2}}{s^{2}}\right)^{\gamma} d s \\
& B\left(\alpha_{i}, \xi\right)=\int_{0}^{\xi}\left(\frac{1-s^{2}}{s^{2}}\right)^{\gamma} d s \\
& \gamma=\frac{1}{2}-\frac{\alpha_{i}}{\pi}
\end{aligned}
$$

and the value of $\xi_{P}$ is found by iteration from

$$
B\left(\alpha_{i}, \xi_{P}\right)=\frac{r_{i}}{h_{i}} \cos \alpha_{i} B\left(\alpha_{i}, 1\right)
$$

The variable $\eta$ is the imaginary part of the complex variable to whose plane the wedge geometry is mapped. From (26) and (37), we find the required load-displacement relationship

$$
P_{i}^{*}=\frac{\delta_{B}^{*}}{2\left[F\left(\eta_{O}\right)-F\left(\eta_{P}\right)\right]}
$$

where the values of $\eta_{P}$ and $\eta_{O}$ are found by iteration from 


$$
\begin{gathered}
A\left(\alpha_{i}, \eta_{P}\right)=\frac{r_{i}}{h_{i}} \cos ^{2} \alpha_{i} B\left(\alpha_{i}, 1\right) \\
A\left(\alpha_{i}, \eta_{O}\right)=\cos \alpha_{i} B\left(\alpha_{i}, 1\right)
\end{gathered}
$$

Note that $\mathrm{P}^{*}{ }_{\mathrm{i}}$ depends on the crack opening displacement, $\Delta \mathrm{v}$, through (41), (43), and (see Figures 2 and 4)

$$
2 r_{i} \cos \alpha_{i}+\Delta v=h_{i}
$$

\section{CONDITIONS FOR INTERFERENCE TO OCCUR}

Certain physical conditions must be satisfied if the applied stresses are to induce interference at a given pair of wedges. One of these is that the relative crack face shear displacement must be in the sense that moves the wedges toward, rather than away from, each other. Thus, from (24), $\Delta u$ must exceed $\Delta v \tan \alpha$. This and (29) imply that $A_{1}>0$, which leads to the restrictions in Table 1 , where

$$
\phi=\frac{\tan (\beta-\alpha)}{\tan \beta}
$$

Table 1. Restrictions on Stress Ratio. If these are not satisfied, interference does not occur. The quantity $\phi$ is defined in (46).

\begin{tabular}{|c|c|c|}
\hline$\beta^{*}=\alpha-90^{\circ}$ & $\sigma_{1}>0$ & $\sigma_{1}<0$ \\
\hline $0 \leq \beta \leq 90^{\circ}$ & $\rho<\phi$ & $\rho>\phi$ \\
\hline$\beta^{*}<\beta<0$ & $\rho>\phi$ & $\rho<\phi$ \\
\hline$-90^{\circ} \leq \beta \leq \beta^{*}$ & $\rho<\phi$ & $\rho>\phi$ \\
\hline
\end{tabular}

If the restrictions in Table 1 are not satisfied, the remote stress field does not bring the wedges into contact and interference does not occur.

The four possible combinations of tensile and compressive principal stress to which a two-dimensional crack may be subjected are labeled as cases I through IV in Table 2. The points $(\rho, \beta)$ for which the various cases produce interference are illustrated in Fig. 6 . In all cases except $I$, there are intervals of the stress orientation angle, $\beta$, for which $\rho$ is unrestricted (every value of $\rho$ produces interference). These intervals are listed in Table 3. 
Table 2. Stress Cases. The four possible combinations of tensile and compressive principal stress are labeled in the rightmost column.

\begin{tabular}{|c|c|c|c|}
\hline$\sigma_{1}$ & $\sigma_{2}$ & $\rho$ & Case \\
\hline$>0$ & $\geq 0$ & $\geq 0$ & I \\
\hline$>0$ & $\leq 0$ & $\leq 0$ & I I \\
\hline$<0$ & $\geq 0$ & $\leq 0$ & I I I \\
\hline$<0$ & $\leq 0$ & $\geq 0$ & IV \\
\hline
\end{tabular}

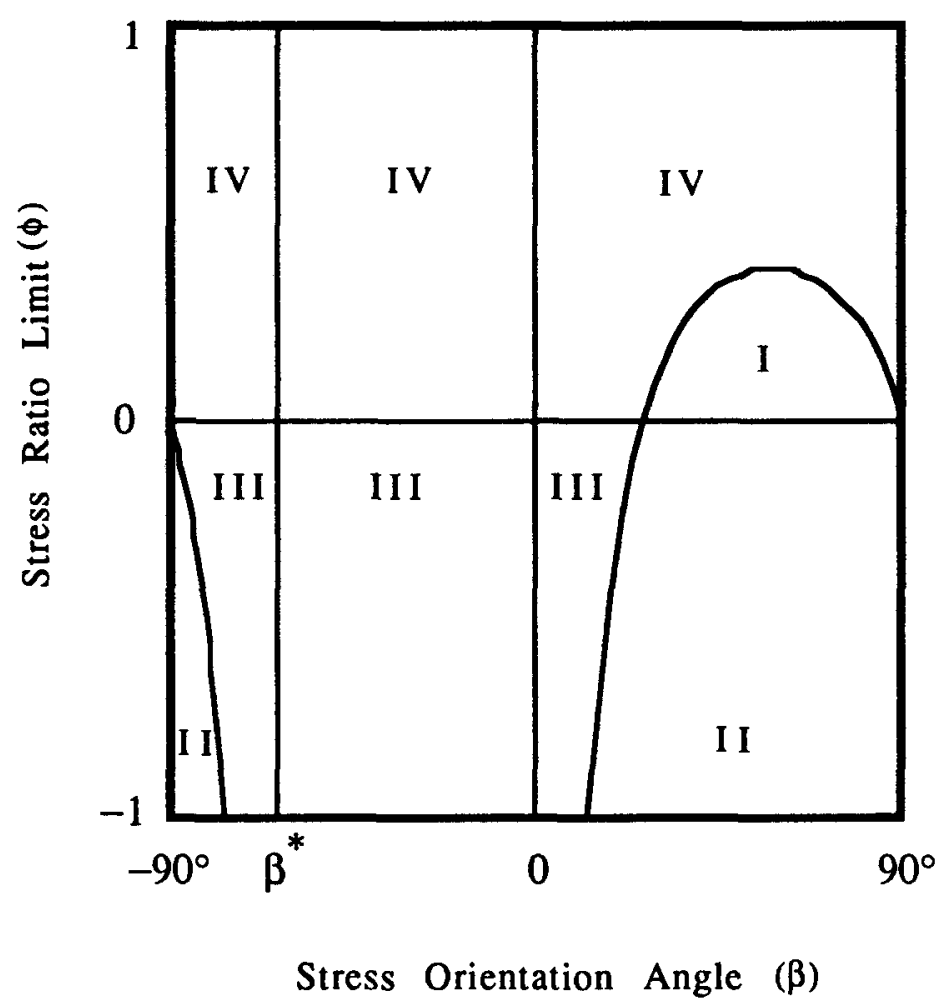

Figure 6. Regions in Which the Various Stress Cases Produce Interference. The curved lines are the quantity $\phi$ defined in (46). The lines $\beta=0$ and $\beta=\beta^{*}$ are asymptotes $\left(\beta^{*}=\alpha-90^{\circ}\right)$. Between them, $\phi>1$. The region labels follow from (46) and Tables 1 and 2 . For each stress case, the ratio of the labeled area to $\pi$ [the area corresponding to all possible points $(\rho, \beta)$ for one case] is a measure of the likelihood that interference will occur. Thus, for the value of $\alpha$ used here $(\tan \alpha=1 / 2)$, the likelihood of having interference is much greater for biaxial compression (case IV) than it is for biaxial tension (case I). 
Table 3. Intervals of Unrestricted Stress Ratio. In these intervals, every value of the stress ratio, $\rho$, produces interference.

\begin{tabular}{|l|c|}
\hline Case & Interval \\
\hline I I & $\alpha<\beta<90^{\circ}$ \\
\hline II I & $-90^{\circ}+\frac{\alpha}{2}<\beta<\frac{\alpha}{2}$ \\
\hline IV & $-90^{\circ}<\beta<\alpha$ \\
\hline
\end{tabular}

Dependence of the I - IV boundary ( $\phi$ in the first quadrant of Figure 6) is illustrated in Figure 7. As the wedge half-angle, $\alpha$, decreases, the region in which biaxial tension (case I) produces interference increases in size, while that for biaxial compression (case IV) decreases.

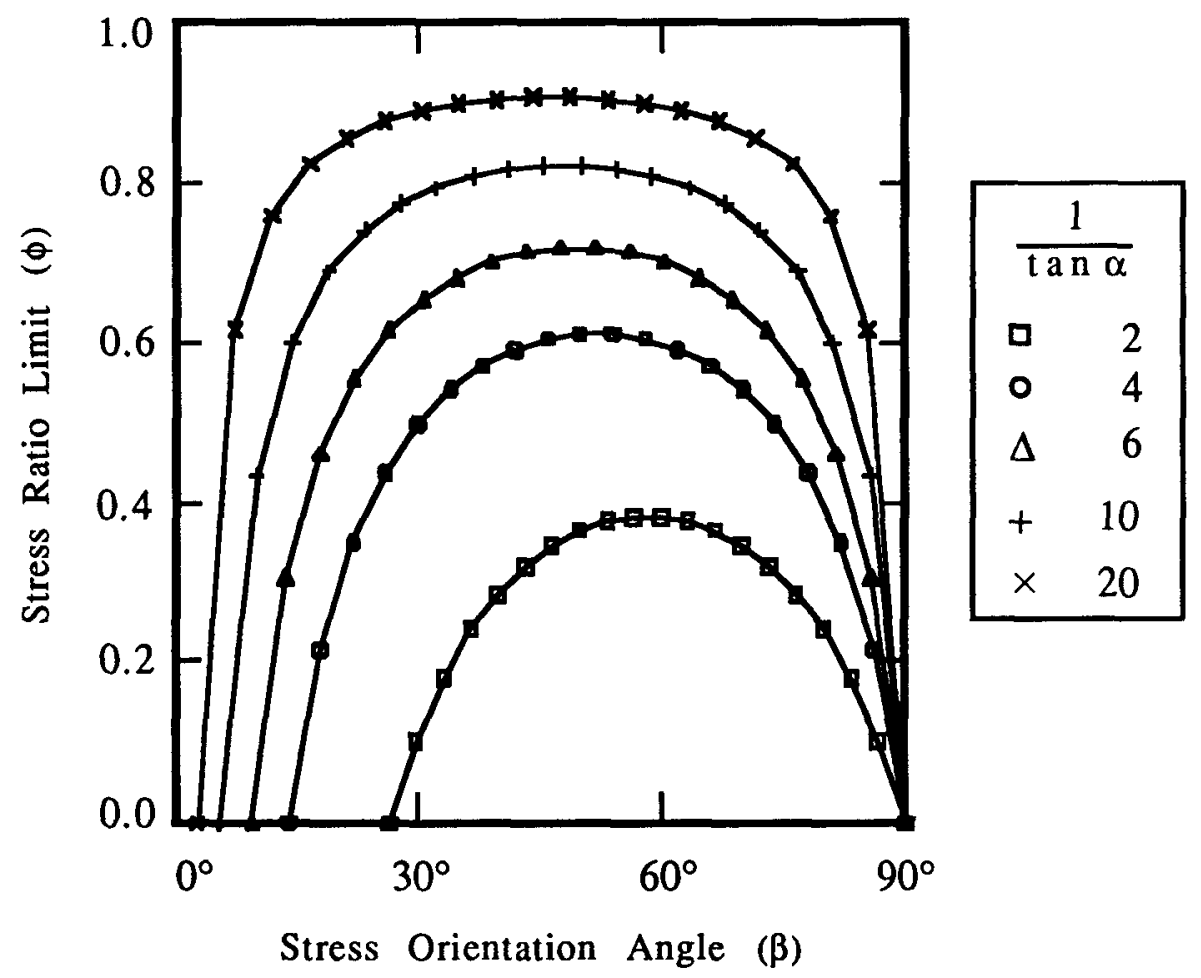

Figure 7. Dependence of Boundary between Stress Cases I and IV on Wedge Half-Angle, $\alpha$. The region below the curve is stress case $I$, and that above the curve is case IV [see (46), Table 2, and Fig. 6]. As $\alpha$ decreases (wedge sharpens), the region in which biaxial tension (case I) produces interference grows, while that in which biaxial compression (case IV) produces interference shrinks. 
The value of the contact force at site " $\mathrm{i}$ " is limited to the range

$$
0<\mathrm{P}_{\mathrm{i}}^{*}<\frac{\mathrm{A}_{1}}{\mathrm{~A}_{2 \mathrm{i}}}
$$

because the contact force is necessarily compressive (left-hand inequality) and cannot exceed what would be provided by a rigid wedge (right-hand inequality).

Another physical restriction that must be satisfied if interference is to occur at a potential interference site is that the crack opening displacement there must be small enough so that the protrusions overlap. This implies that the opening displacement not exceed the protrusion height, or

$$
0<\left.\Delta \mathbf{v}\right|_{x=b}<h
$$

The left-hand inequality precludes interpenetration of the crack faces. To satisfy the right-hand inequality, the applied stresses must not be too large. (This restriction applies to all protrusions of height $h$, regardless of shape, as well as to cracks with "jogs" of length $h$.) The stress required to produce $\Delta \mathrm{v}=\mathrm{h}$ at $\mathrm{x}=\mathrm{b}$ is

$$
\sigma_{h}^{*}=\frac{2 h}{(\kappa+1) D_{I} \sqrt{a^{2}-b^{2}}}
$$

Interference can occur only if $\sigma^{*}<\sigma_{h}^{*}$. For a given stress field and protrusion height, $\sigma_{h}^{*}$ is smallest when the interference site is at the center of the crack $(b=0)$. It follows that interference can occur at the center, and therefore everywhere on the crack, only if

where

$$
\sigma^{*}<\sigma_{M}^{*}
$$

$$
\sigma_{M}^{*}=\frac{2 h}{(\kappa+1) D_{I} a}
$$

\section{CONDITIONS FOR INTERFERENCE TO INFLUENCE FRACTURE}

We now consider whether interference is expected to influence fracture. If the protrusions still overlap [See (48) and (50).] when the stress is raised to $\sigma^{*}=\sigma_{0}^{*}$ [the fracture stress in the absence of interference, (19)], 
then any interference will change the fracture stress from $\sigma_{0}^{*}$ to $\sigma_{F}^{*}$ in (17). Hence, the presence of any interference will influence fracture whenever

From (4), (19) and (20), we have

$$
\sigma_{M}^{*}>\sigma_{0}^{*}
$$

$$
\sigma_{0}^{*}=\frac{K_{I C}}{\mu \sqrt{\pi a\left(D_{I}^{2}+D_{I I}^{2}\right)}}
$$

Since $\sigma_{0}^{*}$ is proportional to $\mathrm{a}^{-1 / 2}$ and $\sigma_{\mathrm{M}}^{*}$ is proportional to $1 / \mathrm{a}$, it follows that for some crack half-length, say $a_{c}$,

$$
\sigma_{M}^{*}=\sigma_{0}^{*}
$$

For all smaller cracks, $\sigma_{0}^{*}$ is less than $\sigma_{M}^{*}$. Hence, for these cracks, the presence of interference implies a change in the fracture stress.

From (51), (53) and (54), we find the critical crack length

$$
2 \mathrm{a}_{\mathrm{c}}=2 \pi\left[\frac{2 \mu \mathrm{h}}{(\kappa+1) \mathrm{K}_{\mathrm{IC}}}\right]^{2}\left[1+\left(\frac{\mathrm{D}_{\mathrm{II}}}{\mathrm{D}_{\mathrm{I}}}\right)^{2}\right]
$$

The last term depends only on the stress field parameters $\rho$ and $\beta$, and is strictly nonnegative. Hence the crack length below which any interference influences fracture satisfies

$$
2 a_{c} \leq 2 \pi\left[\frac{2 \mu h}{(\kappa+1) K_{\mathrm{IC}}}\right]^{2}
$$

For plane stress, this reduces to

$$
2 \mathrm{a}_{\mathrm{c}} \leq \frac{\pi}{8}\left[\frac{\mathrm{Eh}}{\mathrm{K}_{\mathrm{IC}}}\right]^{2}
$$

where we have used (36) and 


$$
\mu=\frac{E}{2(1+v)}
$$

and $E$ is Young's modulus.

Calculations based on (57) are presented in Table 4. The values used for protrusion height, " $h, "$ are typical grain sizes. All data are taken from the literature ${ }^{12}$. Since typical room-temperature crack lengths for the materials considered are much less than the values computed for $a_{c}$, we conclude that the presence of interference changes the fracture stress.

Table 4. Critical Crack Length. For cracks smaller than $a_{c}$, the presence of interference alters the fracture stress. Data in the first three columns are from the literature ${ }^{12}$. Values of $a_{c}$ are computed from (57).

\begin{tabular}{|c|c|c|c|c|}
\hline & $\mathrm{K}_{\mathrm{IC}}\left(\mathrm{MPa} \mathrm{m} \mathrm{m}^{-1 / 2}\right)$ & $\mathrm{E}(\mathrm{GPa})$ & $\mathrm{h}(\mu \mathrm{m})$ & $\mathrm{a}_{\mathrm{c}}(\mathrm{mm})$ \\
\hline $\mathrm{SiC}$ & 5 & 43 & 1.4 & 5.7 \\
\hline $\mathrm{Si}_{3} \mathrm{~N}_{4}$ & 5 & 200 & 1.0 & 0.6 \\
\hline
\end{tabular}

\section{ACCURACY OF CONCENTRATED LOAD MODEL}

As indicated above, replacing the wedges with concentrated loads acting at their bases gives accurate results far from the wedges. But how far away is far enough? This question must be answered to determine how large the wedges can be relative to the crack size, how close an interference site can be to the crack tip, and how close two neighboring sites can be to each other, without compromising the accuracy of the concentrated load model. The question can be resolved through comparison of the stress field around the wedges with that generated by the concentrated loads.

In solving problem $A$, we have used the representation of the interference region depicted in Figure 5. But the correct representation is that shown in Figure 4. We seek to establish the condition under which the representation of Figure 5 is an accurate approximation to that of Figure 4. To accomplish this, we expand the Goursat potential function in the solution to problem $B$ into an infinite series about the point $(h \tan \alpha, h)$ in Figure 4 . The first and second terms of the series are potential functions for the concentrated forces and moments, respectively, in Figure 5. Subsequent terms change the series to that for the potential function appropriate for Figure 4. Near the wedge, these subsequent terms are important. But at some distance from the wedge ("far" from the wedge), they are negligible. The distance in question is that for which the third term of the series is much less in magnitude than the second term. This requirement leads to

$$
\frac{\mathrm{x}}{\mathrm{h}} \gg \mathrm{d}
$$


where

$$
\begin{gathered}
\mathrm{d}=\tan \alpha+\frac{\frac{2 \gamma}{\xi_{\mathrm{P}}}+\xi_{\mathrm{P}}-\Gamma}{\mathrm{B}(\alpha, 1) \cos \alpha} \\
\Gamma=\sum_{\mathrm{n}=0}^{\infty} C_{\mathrm{n}}^{\gamma} \frac{(-1)^{\mathrm{n}}}{1-2 \mathrm{n}}
\end{gathered}
$$

and the $C_{n}^{\gamma}$ are coefficients of the binomial expansion.

Condition (59) implies that the present model is accurate only if each interference site is much farther from its nearest neighbor (another site or a crack tip) than " $h$ " times the normalized distance "d" in (60). When $n$ equally spaced sites are present, the requirement for site " $\mathrm{i}$ " is

$$
\frac{h_{i}}{a}<\frac{2}{(n+1) d_{i}}
$$

Since it depends on the wedge half-angle and the location of the contact load on the wedge face, $d_{i}$ is not the same for each site.

\section{ITERATION PROCEDURE}

The correct values of $\mathrm{P}^{*}, \mathrm{i}=1,2, \ldots, \mathrm{n}$, are those for which (26) is satisfied simultaneously at all interference sites. These can be found by the following iteration procedure. First, choose an applied stress within the limits of (48). Then guess $\mathrm{P}^{*}{ }_{\mathrm{i}}, \mathrm{i}=1,2, \ldots, \mathrm{n}$, within the limits of (47). Use (28) to compute $\delta_{A}^{*}$, which is the wedge bending displacement required by problem A. Then because of (26), put $\delta_{A}^{*}$ from (28) into (42), once for each site. This gives the values of $\mathrm{P}_{\mathrm{i}}^{*}$ for problem $\mathrm{B}$ corresponding to the $\delta_{\mathrm{A}}^{*}$ at each site. It is not difficult to show that if a guessed value of $\mathrm{P}_{i}^{*}$ is higher/lower than the correct value, the value of $P_{i}^{*}$ from (42) is necessarily lower/higher. A bisection procedure guided by this fact converges rapidly to the correct values of the entire set of contact loads, $P_{i}^{*}$. Given these, we can compute $R$ from (14), (15), (18), (20) and (21). The iteration also yields the location of each 
contact load on the wedge face ("r" in Figure 4). From this and (41), $\xi_{P}$ can be computed and the accuracy condition (59) checked.

\section{RESULTS AND CONCLUSIONS}

We show results only for stress case I (biaxial tension), for which the middle column of Table 1 applies.

\section{SINGLE INTERFERENCE SITE}

For a single interference site, the influence of various parameters on the required fracture toughness ratio $[R$ in $(21)]$ is illustrated in Figures 8 through 13. In these figures, the abscissa is $\sigma^{*}$ from (5). The range of $\sigma^{*}$ is set by (48). Specifically, we use values of $\sigma^{*}$ that give an initial crack opening displacement that varies from 0.05 to 0.95 times the wedge height, "h".
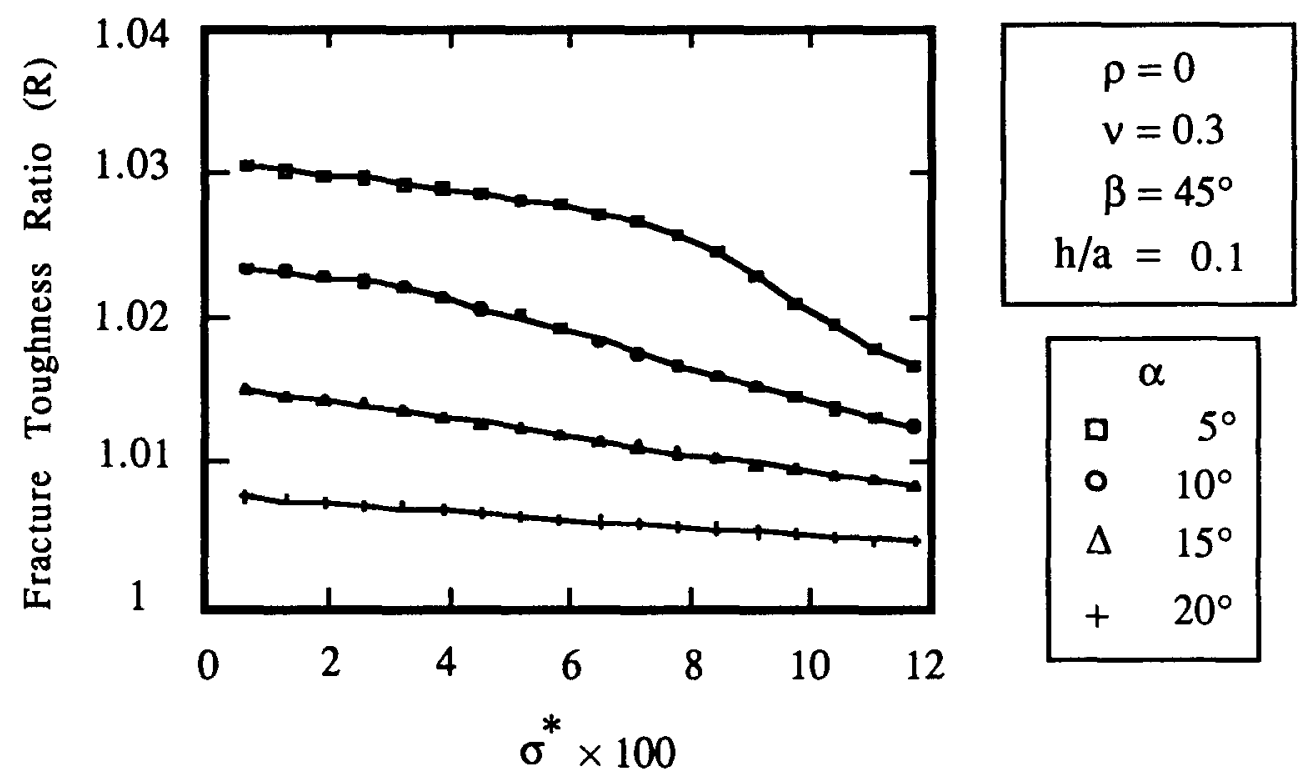

Figure 8. Dependence of the Required Fracture Toughness Ratio on the Wedge Half-Angle, $\alpha$. The ordinate, $R$, is the ratio of the fracture toughness required when interference is absent to that required when interference is present. The interference site is located at the center of the crack. Narrower wedges have steeper sides, and so present more of a barrier to relative shear displacement than do broader wedges. For a given wedge, increasing the applied stress moves the contact force closer to the apex, where the wedge is more flexible. Thus, the contact force generated by a given relative shear displacement, and so the significance of interference, decreases. From (46), Table 1 , and the value of $\rho$ and $\beta$, interference occurs only for $\alpha<26.6^{\circ}$. 


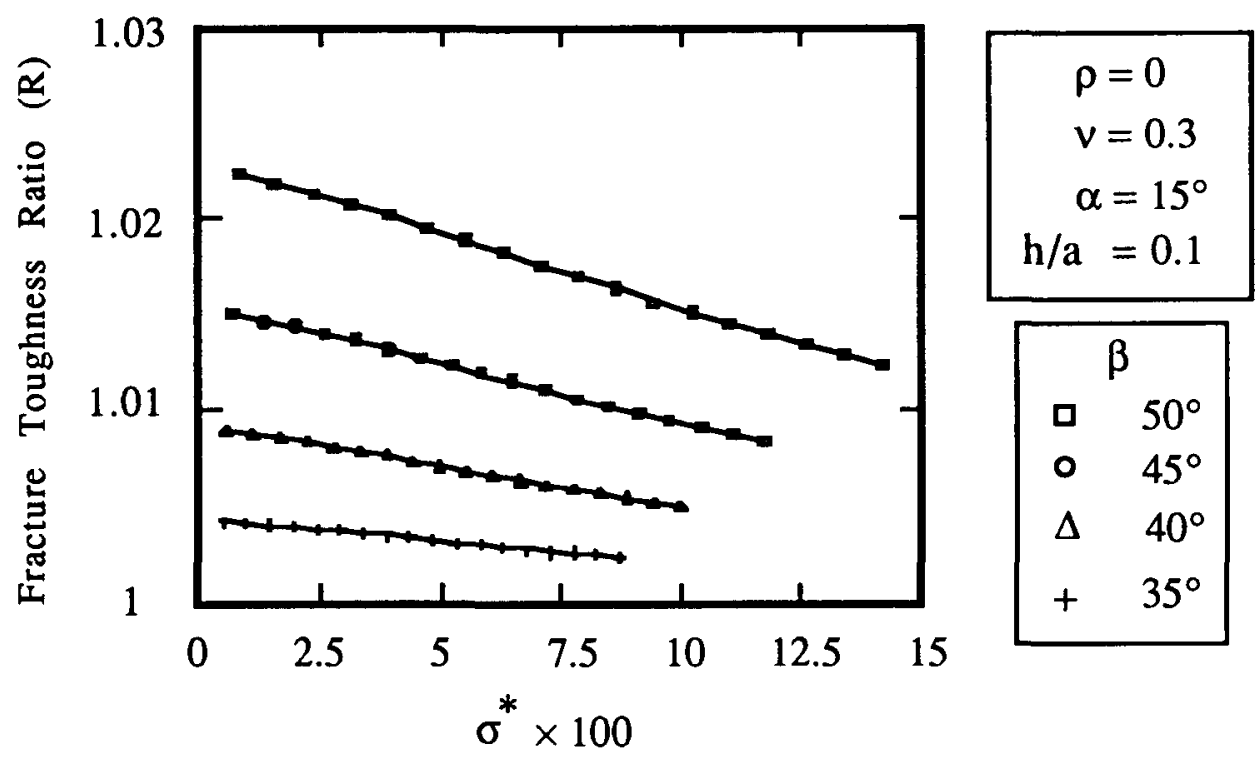

Figure 9. Dependence of the Required Fracture Toughness Ratio on Orientation of the Applied Stress. The interference site is located at the center of the crack. In the absence of interference, the relative shear displacement of the crack faces is maximum for $\beta=45^{\circ}+\alpha / 2 \quad\left(\beta=52.5^{\circ}\right)$. Hence, the influence of interference increases as $\beta$ approaches this value.

The dependence of $R$ on the wedge half-angle, $\alpha$, is illustrated in Figure 8. As $\sigma^{*}$ increases, the contact force moves nearer to the apex of the wedge. Consequently, the flexibility of the wedge increases and the curves shown have negative slopes. The drop-off is more pronounced for the narrower wedges. The significance of the interference decreases for broader wedges because for a given crack opening displacement, they allow greater relative shear displacement before contact occurs.

The dependence of $R$ on the stress orientation angle, $\beta$, is illustrated in Figure 9. If the wedges offered no resistance to bending, their bending displacement would be maximum for $\beta=52.5^{\circ}$. [See (28), (29), (31) and (32) with $\left.\alpha=15^{\circ}, \rho=0, P_{j}^{*}=0.\right] \quad$ Consequently, the effect of interference increases as $\beta$ approaches $52.5^{\circ}$.

The dependence of $R$ on the biaxial stress ratio defined in (6) is illustrated in Figure 10. The stress $\sigma_{2}$ produces relative crack-face shear displacement opposite to that produced by $\sigma_{1}$. Hence, as the ratio of $\sigma_{2}$ to $\sigma_{1}$ increases, the net relative shear displacement, as well as the influence of interference, decreases.

As shown in Figure 11, variation of Poisson's ratio within physically realistic limits has little effect on $R$.

The dependence of $R$ on the size of the wedge is illustrated in Figure 12. As one would expect, larger wedges produce greater changes in the 

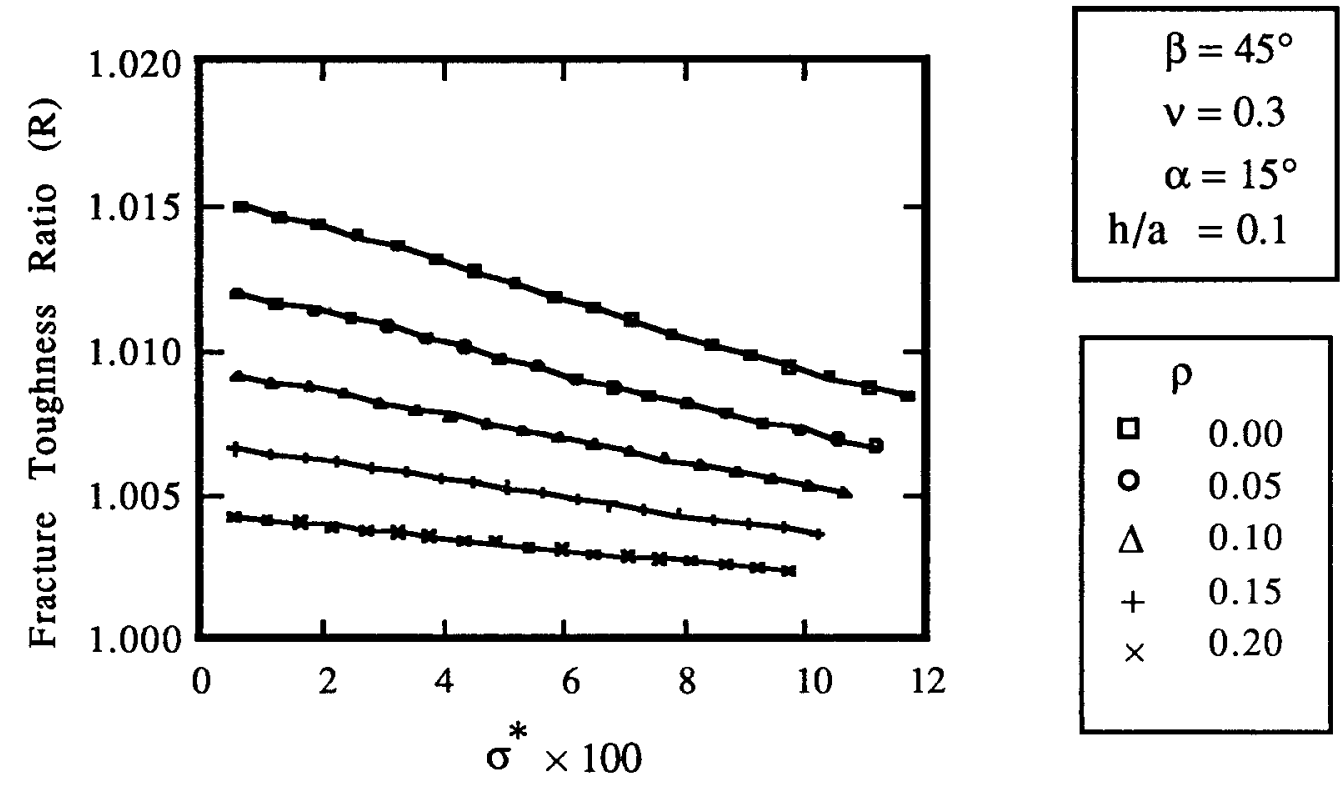

Figure 10. Dependence of the Required Fracture Toughness Ratio on the Stress Ratio, $\rho$. Both stresses are tensile. The interference site is located at the center of the crack. Because the relative shear displacements produced by the two principal stresses oppose each other, increasing the stress ratio reduces interference.

required fracture toughness. It is clear that if the wedges are too large relative to the crack size, replacing the wedges with concentrated loads in problem $A$ is not appropriate.

In Figure 13, dependence of the change in required fracture toughness on the location of the interference site is illustrated. As the interference site approaches the crack tip, the change in required fracture toughness increases. This is to be expected. The nearer the site is to the crack tip, the greater its influence on the crack tip stress state.

\section{MULTIPLE INTERFERENCE SITES}

From the results shown in Figures 8 through 13, it is clear that the influence of protrusion interference at a single site on the fracture toughness required to prevent unstable crack propagation is slight. In a real crack with rough faces, protrusion interference would not, in general, be limited to a single interaction site. Consequently, the effect of multiple interaction sites must be considered before the significance of protrusion interference can be established.

When multiple interaction sites are present, it is not always clear which crack tip, $x=a$ or $x=-a$, is more affected by the interference. But we show results only for site distributions that are symmetric about $x=0$. Hence, both tips are almost equally affected.

Figure 14 shows the influence of the number of sites on the fracture toughness ratio, $R$. The fact that the influence increases monotonically with 


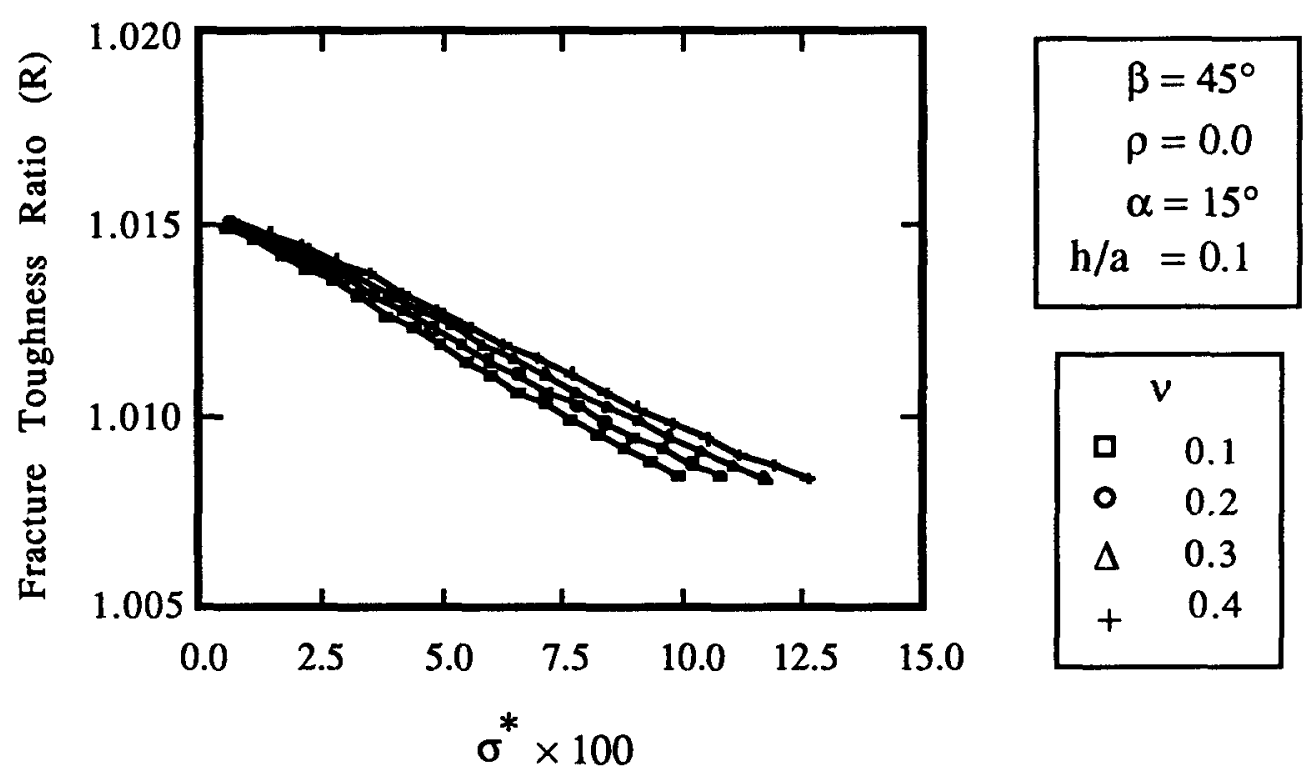

Figure 11. Dependence of the Required Fracture Toughness Ratio on Poisson's Ratio. The interference site is located at the center of the crack. Variation of Poisson's ratio within realistic limits has little influence on the amount of interference.

the number of sites is not surprising. The greater the number of sites, the more shear is carried by the protrusions and the less by the crack tips. Because of this result, one would expect the influence of interference to be substantial when it occurs at many sites.

Given that the influence of interference increases with the number of interaction sites, it is logical to consider extending the results shown in Figure 14 to include a large number of sites. But, as is now shown, the present model would not give accurate results in this case. Figure 15 shows the dependence of the normalized required separation distance, " $d$ " (60), on the normalized crack opening. As the crack is opened, the contact load moves up the side of the wedge [See Figures 2 and 4.] This increases the relative magnitude of the higher order terms in the Goursat potential series, so that the region in which the approximation associated with Figure 5 is inaccurate grows. From (62) and Figure 15, we see that for a given crack length and wedge geometry, increasing the number of sites or the remote stress level eventually renders the present model inaccurate.

\section{RECOMMENDATIONS}

Although mathematically convenient, the wedge geometry used in the present model is probably not realistic. Specifically, the region adjacent to the wedge on the side opposite the contact force (see Figures 2 and 4) is not empty. If the missing material were filled in on this "back" side of each wedge, the geometry of Figure 2 would change to that of a line crack with a "step" at the interference site. The methods used herein could be extended to accommodate this geometry. Since the wedge is more flexible than the step, 


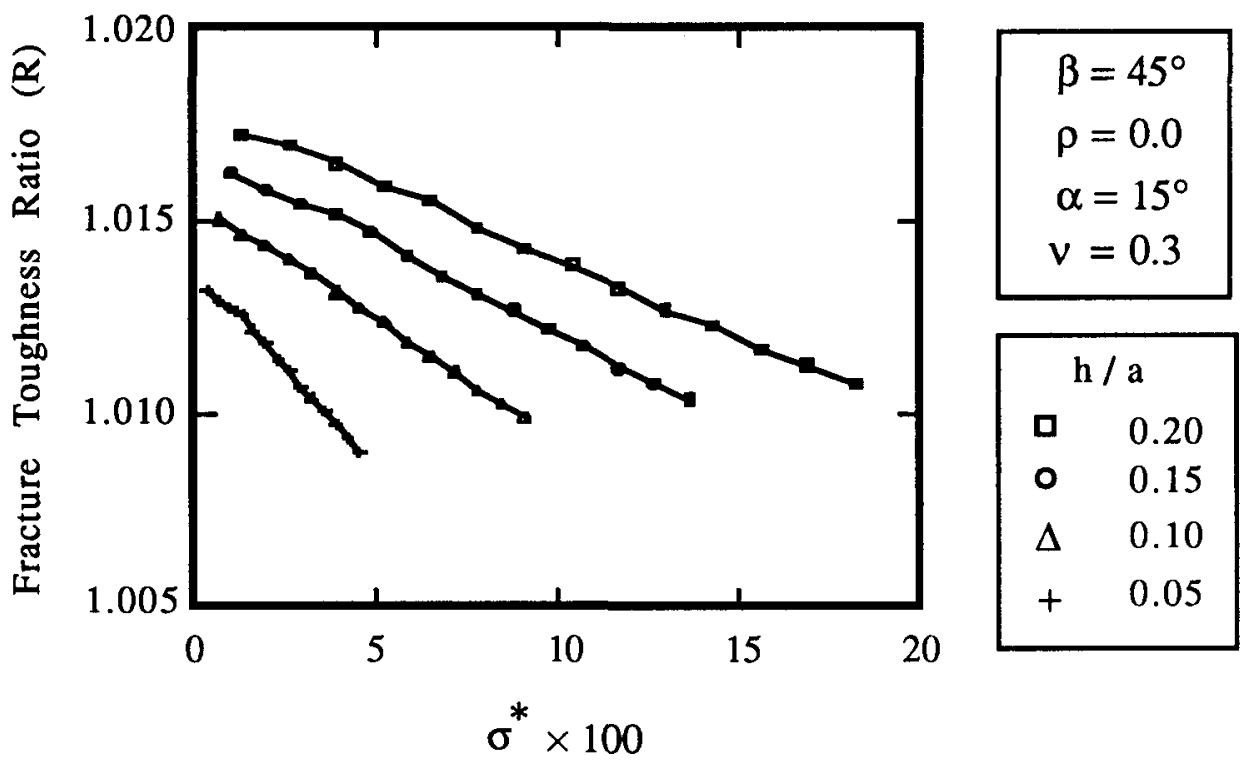

Figure 12. Dependence of the Required Fracture Toughness Ratio on Wedge Size. The interference site is located at the center of the crack. As the wedge height increases, so does the interference.

use of the wedge could significantly underestimate the importance of the interference. To determine the error associated with using the wedge shape, more realistic protrusion geometries should be investigated.

The fact that the influence of interference increases with the number of sites indicates that the extent of this influence cannot be calculated unless cracks with many closely spaced sites can be modeled. Because the present model is not accurate when interference sites are near each other or near the crack tips, the model should be improved to accommodate closely spaced sites. This amounts to changing the mapping function used in problem $B$ to that for a jagged crack.

Once the recommendations listed above have been followed, the influence of protrusion interference on unstable propagation of line cracks will be established. If that influence is significant, it would be appropriate to generalize the above method to accommodate a three-dimensional model. Such a model could include, for instance, a penny-shaped crack in triaxial stress with interference sites at various places on the crack. Clearly, the portion of this model corresponding to problem $B$ (concentrated force on the side of a protrusion), above, as well as the kinematics of the displacement compatibility condition, would be far more complicated than they are in the model presented here.

It is unreasonable to expect to know precise protrusion geometries and interference locations for a real crack. However, it is reasonable to expect to know key parameters of statistical distributions of protrusion geometries and interference locations for a real crack. Given these, a protrusion interference model like that presented here could be incorporated in a simulation (based, for instance, on Monte Carlo methods) to predict the influence of 


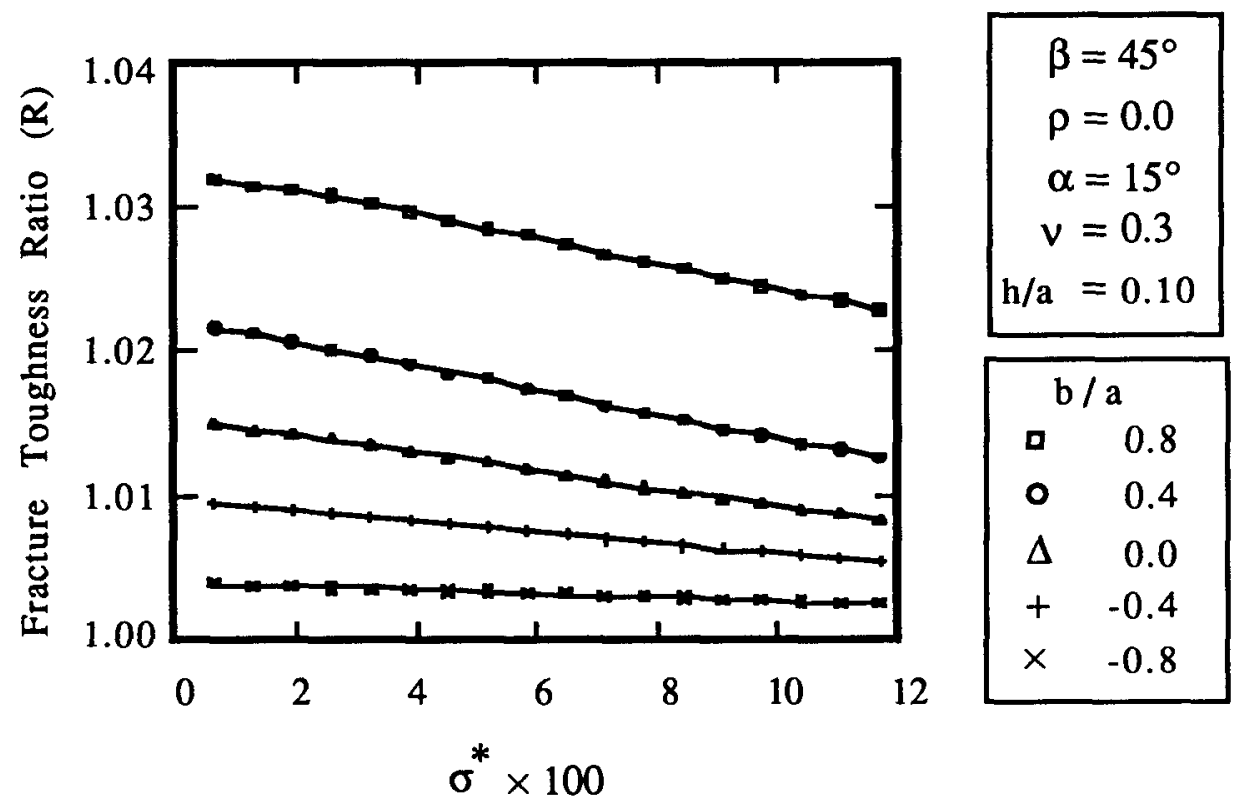

Figure 13. Dependence of the Required Fracture Toughness Ratio (at $x=a$ ) on the Location of the Interference Site. As the interference site approaches the crack tip, the influence of the interference on the fracture toughness required at the crack tip increases.

interference on the likelihood of fracture. If interference is important for arbitrarily specified crack geometries, then a simulation should be done.

Given the ability to simulate interference in real cracks, a procedure for incorporating the results of simulation into current design practices should be explored.

Finally, it should be noted that the concentrated load method used here in analysis of protrusion interference can be adapted to other kinds of crack-face interaction. For instance, it could be used to study Mode $I$ crack opening of fiber-reinforced composites. The fact that crack bridging occurs at discrete fibers, rather than via a continuous traction, suggests that the concentrated load model is the more natural one for this problem. 


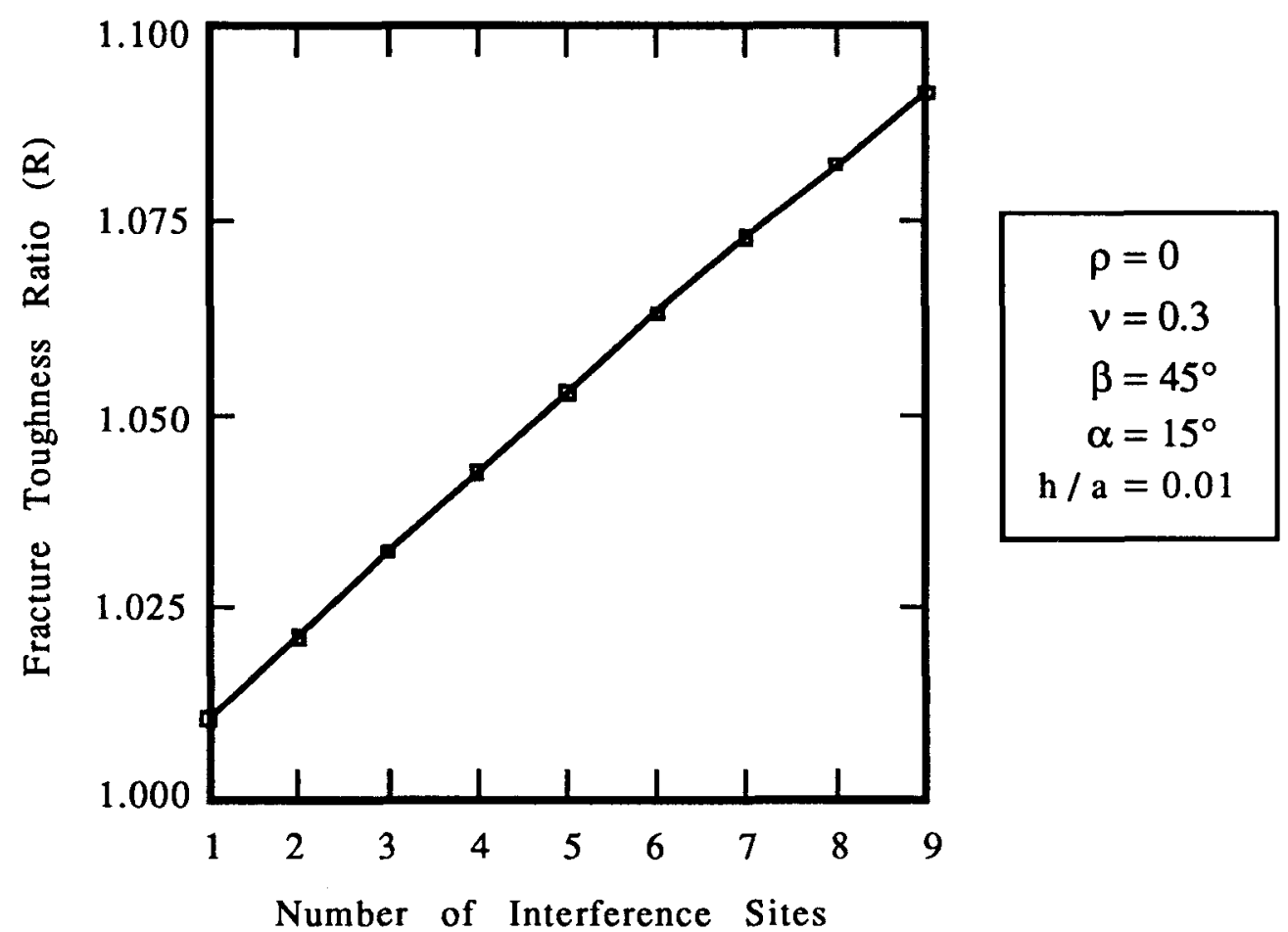

Figure 14. Influence of Number of Interference Sites on Required Fracture Toughness. Applied (remote) stress is that which, in the absence of interference, opens the crack center a distance equal to five per cent of the wedge height $(\Delta v / h=0.05$ at $x=0)$. As the number of sites increases, so does the influence on required fracture toughness. The smaller the wedge height relative to the crack length, the less the influence of the interference. 


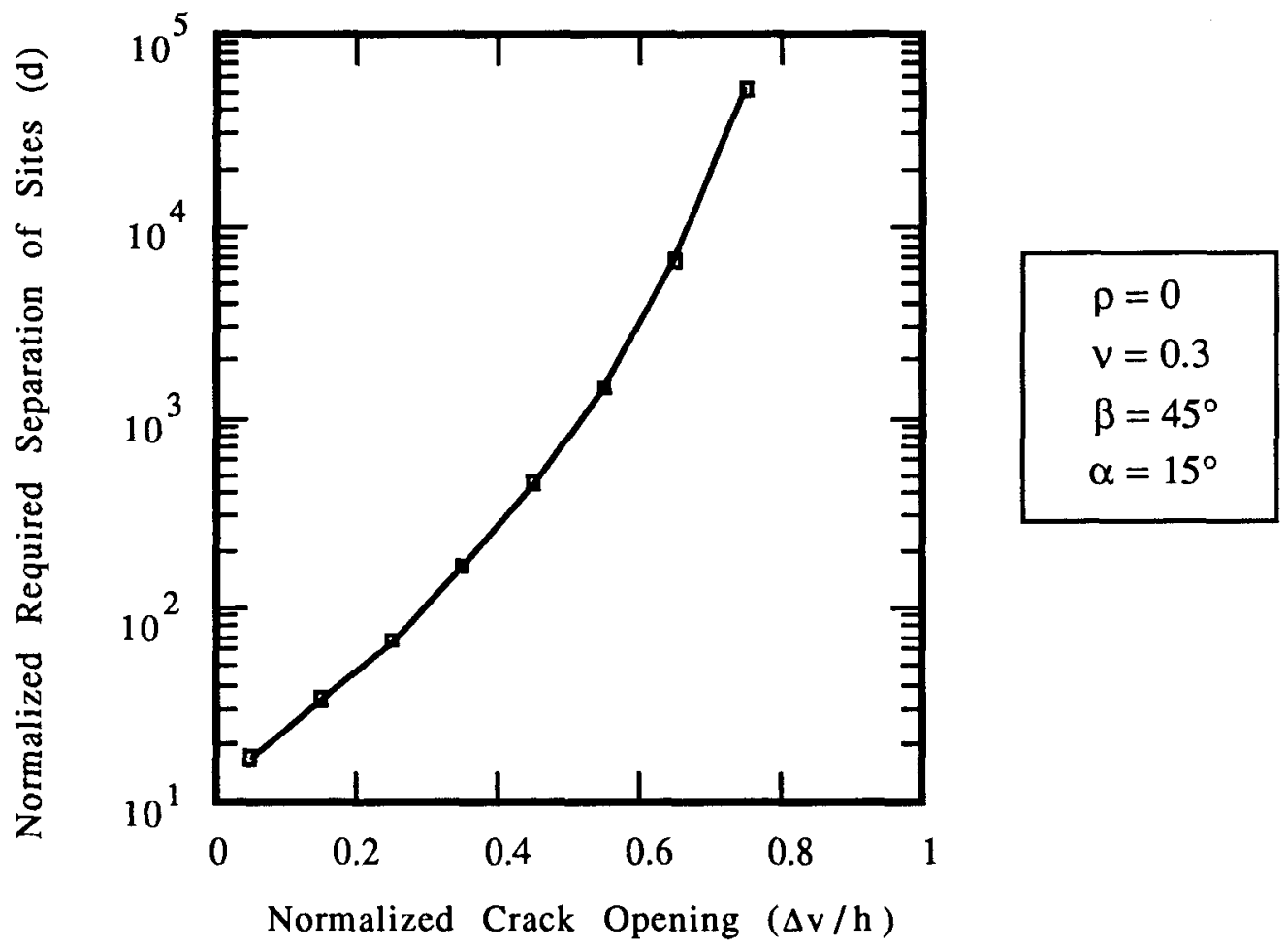

Figure 15. Required Separation of Interference Sites. As the crack opens, the contact load moves up the wedge face. This increases the distance on either side of the wedge at which the approximation of the present model becomes inaccurate. 


\section{REFERENCES}

1. H. M. Westergaard, "Bearing Pressures and Cracks," J. of Applied Mech. 6(2) A-49, 1939.

2. D. R. Clarke, B. R. Lawn, and D. H. Roach, "The Role of Surface Forces in Fracture," pp. 341-350 in Fracture Mechanics of Ceramics,Volume 8, ed. R. C. Bradt et al., Plenum Press, 1986.

3. C. J. Fairbanks et al., "Microstructure and the Strength of Ceramics," pp. 23-37 in Fracture Mechanics of Ceramics, Volume 8, ed. R. C. Bradt et al., Plenum Press, 1986.

4. D. B. Marshall and A. G. Evans, "The Tensile Strength of Uniaxially Reinforced Ceramic Fiber Composites," pp. 1-15 in Fracture Mechanics of $\mathrm{Ce}$ ramics,Volume 7, ed. R. C. Bradt et al., Plenum Press, 1986.

5. M. F. Kanninen and C. H. Popelar, Advanced Fracture Mechanics, Oxford University Press, 1985.

6. J. F. Knott, Fundamentals of Fracture Mechanics, Butterworths, London, 1973.

7. F. Erdogan, "On the Stress Distribution in Plates with Collinear Cuts under Arbitrary Loads," pp. 547-553 in Proceedings of the Fourth U.S. National Congress of Applied Mechanics, Vol. 1, ed. R. M. Rosenberg, ASME, 1962.

8. P. Paris and G.C. Sih, "Stress Analysis of Cracks," pp. 67-68 in Fracture Toughness Testing and Its Applications, STP 381, ASTM, 1965.

9. A. H. England, Complex Variable Methods in Elasticity.,Wiley-Interscience, 1971.

10. N. I. Muskhelishvili, Some Basic Problems from the Mathematical Theory of Elasticity, P. Noordhoff, 1953. 1953.

11. N. I. Muskhelishvili, Singular Integral Equations, P. Noordhoff,

12. Ceramic Source, Vol. I, American Ceramic Society, 1985. 


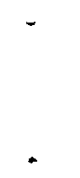




\section{INTERNAL DISTRIBUTION}

1-2. Central Research Library

3. Document Reference Section

4-5. Laboratory Records Department

6. Laboratory Records, ORNL RC

7. ORNL Patent Section

8-10. M\&C Records Office

11. L. F. Allard, Jr.

12. L. D. Armstrong

13. P. F. Becher

14. R. F. Bernal

15. T. M. Besmann

16. P. J. Blau

17. A. Bleier

18. E. E. Bloom

19. K. W. Boling

20. R. A. Bradley

21. C. R. Brinkman

22. V. R. Bullington

23. R. S. Carlsmith

24. P. T. Carlson

25. G. M. Caton

26. S. J. Chang

27. R. H. Cooper, Jr.

28. B. L. Cox

29. D. F. Craig

30. S. A. David

31. J. H. DeVan

32. J. L. Ding

33. M. K. Ferber

34. F. M. Foust

35. W. Futkerson

36. R. L. Graves

37. D. L. Greene

38. M. H. Harris

39. E. E. Hoffman

40. C. R. Hubbard

41. M. A. Janney
42. M. G. Jenkins

43. D. R. Johnson

44. ... F. F. Jones

45. D. Jos Tin

46. R. R. Judkins

47. M. A. Karnitz

48. M. R. Kass

49-53. B. L. P. Keyes

54. H. D. Kimrey, Jr.

55. T. G. Kollie

56. K. C. Liu

57. E. L. Long, Jr.

58. W. D. Maniy

59. R. W. McClung

60. D. J. McGuire

61. J. R. Merriman

62. D. L. Moses

63. T. A. Nolan

64. A. E. Pasto

65. J. L. Rich

66. C. R. Richmond

67. J M Robbins

68. M. L. Santella

69. A. C. Schaffhauser

70. S. Scott

71. G. M. Slaughter

72. E. J. Soderstrom

73. D. P. Stinton

74. R. W. Swindeman

75. V. J. Tennery

76. T. N. Tiegs

77. J. R. Weir, Jr.

78. B. H. West

79. F. W. Wiffen

80. S. G. Winslow

81. J. M. Wyrick

82. C. S. Yust 


\section{EXTERNAL DISTRIBUTION}

83. James H. Adair

University of Florida

Materials Science and

Engineering

317 MAE B1dg.

Gainesville, FL 32611-2066

84. Donald F. Adams

University of Hyoming

Mechanical Engineering

Department

P. O. Box 3295

Laramie, WY 82071

85. Jalees Ahmad

AdTech Systems Research, Inc.

1342 North Fairfield Road

Dayton, OH 45432-2698

86. Yoshio Akimune

NISSAN Motor Co., Ltd.

Materials Research Laboratory

1 Natsushima-Cho

Yokosuka 237

JAPAN AIR MAIL

87. Mufit Akinc

Iowa State University

322 Spedding Hall

Ames, IA 50011

88. IThan A. Aksay

University of Washington

Materials Science and Engineering

Department, FB-10

Seattle, WA 98195

89. R. G. Alexander

BASE

26 Malvern Close

Kettering Northants NN16 AJP

UNITED KINGDOM AIR MAIL

90. Richard L. Allor

Ford Motor Company

Material Systems

Reliability Department

20000 Rotunda Drive

P.0. Box 2053, Room S-2031

Dearborn, MI 48121-2053
91. Richard T. Alpaugh

U.S. Department of Energy

Advanced Propulsion Division

CE-322, Forrestal Building

Washington, DC 20585

92. Joseph E. Amaral

Instron Corporation

Corporate Engineering Office

100 Royale street

Canton, MA 02021

93. Edward M. Anderson

A] uminum Company of America

North American Industrial

Chemicals Division

P.0. Box 300

Bauxite, AR 72011

94. Norman C. Anderson

Ceradyne, Inc.

Ceramic-to-Metal Division

3169 Redhill Avenue

Costa Mesa, CA 92626

95. Don Anson

Battelle Columbus Laboratories

Thermal Power Systems

505 King Avenue

Columbus, OH 43201-2693

96. Thomas Arbanas

G.B.C. Materials Corporation

580 Monastery Drive

Latrobe, PA 15650-2698

97. Frank Armatis

3M Company

3M Center

Building 60-1N-01

St. Paut, MN 55144-1000

98. Everett B. Arnold

Detroit Diesel Corporation

Mechanical Systems Technology

13400 Outer Drive, West

Detroit, MI 48239-4001

99. Richard M. Arons

PA Consulting Group

279 Princeton Road

Hightstown, NJ 08550 
100. Bertil Aronsson

Sandvik AB

S-12680

Stockholm Lerkrogsvagen 19

SWEDEN AIR MAIL

101. Dennis Assanis

University of 111 inois

Department of Mechanical Engineering

1206 H. Green Street

Urbana, IL 61801

102. Williaan H. Atwell

Dow Corning Corporation

3901 South Saginaw Road MS: 540

Midland, MI 48686-0995

103. V. S. Avva

North Carolina A\&T State University

Department of Mechanical Engineering

Greensboro, NC 27411

104. Patrick Badgley

Adiabatics, Inc.

3385 Commerce Drive

Columbus, IN 47201

105. Sunggi Baik

Pohang Institute of Science \& Technology

Department of Materials Science and Engineering

P.0. Box 125

Pohang 790-600

KOREA AIR MAIL

106. John M. Bailey

Caterpillar, Inc.

Technical Center

Building L

P.0. Box 1875

Peoria, IL 61656-1875

107. Bob Baker

Ceradyne, Inc.

3169 Redhill Avenue

Costa Mesa, CA 92626
108. Frank Baker

Aluminum Company of America

Alcoa Technical Center

Alcoa Center, PA 15069

109. J. 6. Baldoni

GTE Laboratories Inc.

40 Sylvan Road

Maltham, MA 02254

110. Clifford P. Ballard

Allied-Signal, Inc.

Ceramics Program

P.0. Box 1021

Morristown, NJ 07962-1021

111. M. Balu

Amoco Performance Products Inc.

4500 McGinnis Ferry Road

Alpharetta, GA 30202

112. B. P. Bandyopadhyay

Toyohashi University of Technology

School of Production Systems Engineering

Tempaku-Cho Toyohashi 440

JAPAN AIR MAIL

113. P. M. Barnard

Ruston Gas Turbines Limited

Metallurgical Laboratory

P. 0. Box 1

Lincoln LN2 5DJ

ENGLAND AIR MAIL

114. Harold N. Barr

Hittman Corporation

9190 Red Branch Road

Columbia, MD 21045

115. Renald D. Bartoe

Vesuvius McDanel

510 Ninth Avenue

Box 560

Beaver Falls, PA 15010-0560

116. Donald M. Bartos

Dow Corning Corporation

Advanced Ceramics Program

Midland, MI 48686-0995 
117. David L. Baty

Babcock \& Wilcox-LRC

P.0. Box 11165

Lynchburg, VA 24506-1165

118. Donald F. Baxter, Jr.

ASM Internationai

Advanced Materials and

Processes

Materials Park, OH 44073-0002

119. M. Brad Beardsley

Caterpillar, Inc.

Advanced Materials Technology

Technical Center B1dg. E

P.0. Box 1875

Peoria, IL 61656-1875

120. Robert Beck

Teledyne CAE

Materials Engineering/Programs

1330 Laskey Road

P.0. Box 6971

Toledo, OH 43612

121. John C. Bell

Shell Research Limited

Thornton Research Centre

P.0. Box 1

Chester, Chl 3SH

ENGLAND AIR MAIL

122. Albert H. Bell, III

General Motors Technical Center 30200 Mound Road

Engineering Building/W3 Turbine

Warren, MI 48090-9010

123. M. Bentele

Xamag, Inc.

259 Melville Avenue

Fairfield, CT 06430

124. Larry D. Bentsen

BF Goodrich Company

RED Center

9921 Brecksville Road

Brecksville, OH 44141

125. Joseph C. Bentz

ENCERATEC

2525 Sandcrest Drive

Columbus, IN 47203
126. Louis Beregszazi

Defiance Precision Products

P.O. Drawer 428

Defiance, $\mathrm{OH} 43512$

127. Tom Bernecki

Northwestern University

BIRL

1801 Maple Avenue

Evanston, IL 60201-3135

128. Charles F. Bersch

Institute for Defense Analyses

1801 North Beauregard Street

ATexandria, VA 22311

129. Ram Bhatt

MASA Lewis Research Center

21000 Brookpark Road

Cleveland, OH 44135

130. Deane I. Biehler

Caterpiliar, Inc.

Engineering and Research Materials

Technical Center, Building E

P.0. Box 1875

Peoria, IL 61656-1875

131. John. W. Bjerklie

Consolidated Natural Gas

Service Co., Inc.

Research Department

CNG Tower

Pittsburgh, PA 15222-3199

132. William D. Bjorndahl

TRW, Inc.

One Space Park

Building 01, Room 2040

Redondo Beach, CA 90278

133. Keith A. Blakely

Advanced Refractory

Technologies, Inc.

699 Hertel Avenue

Buffalo, NY 14207

134. Edward 6. Bl anchard

Netzsch Inc.

119 Pickering Way

Exton, PA 19341 
135. Keith Blandford

Boride Products, Inc.

2879 Aero Park Drive

Traverse City, MI 49684

136. Bruce Boardman

Deere and Company Technical

Center

3300 River Drive

Moline, IL 61265

137. Russell Bockstedt

Hoechst Celanese Corporation

150 JFK Parkway

Short Hills, NJ 07078

138. M. Boehmer

DLR German Aerospace Research Establishment

Postfach 906058

D-5000 Koln 90

GERMANY AIR MAIL

139. Lawrence P. Boesch

EER Systems Corp.

1593 Spring Hill Road

Vienna, VA 22182-2239

140. Donald H. Boone

Boone \& Associates

2412 Cascade Drive

Walnut Creek, CA 94598-4313

141. Tom Booth

Allied-Signal Aerospace Company

AiResearch Los Angeles

Division

2525 West 190th Street

Torrance, CA 90509-2960

142. Tibor Bornemisza

Sundstrand Power Systems

4400 Ruffin Road

San Diego, CA 92186-5757

143. J.A.M. Boulet

University of Tennessee

Department of Engineering

Science and Mechanics

310 Perkins Hall

Knoxville, TN 37996-2030
144. H. Kent Bowen

Massachusetts Institute of Technology

77 Massachusetts Avenue

Room E40-434

Cambridge, MA 02139

145. Lesile J. Bowen

Materials Systems

53 Hillcrest Road

Concord, MA 01742

146. Steven C. Boyce

Air Force Office of

Scientific Research

AFOSR/NA Bldg. 410

Bolling AFB DC 20332-6448

147. Gary L. Boyd

CEC

400 Howell Avenue, No. 4

Warl and, WY 82401

148. Steve Bradley

UOP Research Center

50 East Algonquin Road

Des Plaines, IL 60017-6187

149. Michael C. Brands

Cummins Engine Company, Inc.

P.0. Box 3005

Mail Code 50179

Columbus, IN 47201

150. Raymond J. Bratton

Westinghouse Science and

Technology Center

1310 Beulah Road

Pittsburgh, PA 15235

151. John J. Brennan

United Technologies Corporation

Research Center

Silver Lane, MS:24

East Hartford, CT 06108

152. Jeff D. Bright

Ceramatec, Inc.

2425 South 900 West

Salt Lake City, UT 84108 
153. Terrence K. Brog

Coors Ceramics Company

Corporate Development and Technology

4545 McIntyre Street

Golden, CO 80403

154. Gunnar Broman

317 Fairlane Drive

Spartanburg, SC 29302

155. A1 Brown

High-Tech Materials Alert

P.0. Box 882

Dayton, NJ 08810

156. Jesse Brown

Virginia Polytechnic Institute and State University

Center for Advanced Ceramic Materials

B1acksburg, VA 24061-0256

157. Sherman D. Brown

University of Illinois

Materials Science and

Engineering Department

105 South Goodwin Avenue

204 Ceramics Building

Urbana, IL 61801

158. S. L. Bruner

Ceramatec, Inc.

2425 South 900 West

Salt Lake City, UT 84119

159. Adolfo Brusaferro

Keramont Corporation

4231 South Fremont Avenue

Tucson, AZ 85714

160. H. Bryzik

U.S. Army Tank Automotive Command

R\&D Center

Propulsion Systems Division

Warren, MI 48397-5000

161. S. T. Buljan

GTE Laboratories, Inc.

40 Sylvan Road

Waltham, MA 02254

162. S. J. Burden

GTE Valenite

1711 Thunderbird

Troy, MI 48084

163. Curt V. Burkland

AMERCOM, Inc.

8928 Fullbright Avenue

Chatsworth, CA 91311

164. Bi11 Bustamante

AMERCON, Inc.

8928 Fullbright Street

Chatsworth, CA 91311

165. Oral Buyukozturk

Massachusetts Institute of Technology

77 Massachusetts Avenue

Room 1-280

Cambridge, MA 02139

166. David A. Caillet

Ethyl Corporation

451 Florida Street

Baton Rouge, LA 70801

167. Frederick J. Calnan

Heany Industries, Inc.

249 Briarwood Lane

P.0. Box 38

Scottsville, NY 14546

168. Roger Cannon

Rutgers University

Ceramics Department

P.0. Box 909

Piscataway, NJ 08855-0909

169. Scott Cannon

P.0. Box 567254

Atlanta, GA 30356

170. Harry W. Carpenter

19945 Acre Street

Northridge, CA 91324

171. David Carruthers

Kyocera Industrial Ceramics

Company

P.0. Box 2279

Vancouver, WA 98668-2279 
172. Calvin H. Carter, Jr. Cree Research, Inc. 2810 Meridian Parkway Durham, NC 27713

173. J. David Casey 35 Atlantis Street West Roxbury, MA 02132

174. Jere G. Castor J. C. Enterprise 5078 North 83rd Street Scottsdale, AZ 85250

175. James D. Cawley Case Western Reserve University Materials Science and Engineering Department Cleveland, $\mathrm{OH} 44106$

176. Thomas C. Chadwick Den-Mat Corporation P.0. Box 1729

Santa Maria, CA 93456

177. Ronald H. Chand Chand Kare Technical Ceramics 2 Coppage Drive Worcester, MA 01603

178. Robert E. Chaney EG\&G Idaho, Inc. Idaho National Engineering Laboratory

P.0. Box 1625

Idaho Falls, ID 83415-3525

179. Frank C. Chang

U.S. Army Materials Technology Laboratory

AMTL-EMM

405 Arsenal Street

Watertown, MA 02172

180. Robert $M$. Chapman

Allied-Signal Aerospace

Company

1530 Wilson Boulevard, 10th Floor

Arlington, VA 22209
181. William Chapman

Williams International

Corporation

2280 West Maple Road

Walled Lake, MI 48390-0200

182. Charlie Chen

LECO Corporation

P.0. Box 211688

Augusta, GA 30917

183. Albert A. Chesnes

U.S. Department of Energy

Transportation Technologies

CE-30, Forrestal Building, 6B-094

Washington, DC 20585

184. Kaiyin Chia

Carborundum Company

P.0. Box 832

Niagara Falls, NY 14302

185. Frank Childs

EG\&G Idaho, Inc.

Idaho National Engineering Laboratory

P.0. Box 1625

Idaho Falls, ID 83415-3527

186. William J. Chmura

Torrington Company

59 Field Street

Torrington, CT 06790-4942

187. Tsu-Wei Chou

University of Delaware

Center for Composite Materials

201 Spencer Laboratory

Newark, DE 19716

188. R. J. Christopher

Ricardo Consulting Engineers Bridge Works

Shoreham-By-Sea West Sussex BN43 5FG

ENGLAND

AIR MAIL

189. Joel P. Clark

Massachusetts Institute of Technology

Room 8-409

Cambridge, MA 02139 
190. Giorgio Clarotti

Commission of the European Communities

DGXII-C3, MO75, 1-53;

200 Rue de la Loi

B-1049 Brussels

BELGIUM AIR MAIL

191. W. J. Clegg

ICI Advanced Materials

P.0. Box 11

The Heath, Runcorn Cheshire

WA7 4QE

ENGLAND AIR MAIL

192. Joseph Cleveland

GTE Products Corporation

Hawes Street

Towanda, PA 18848-0504

193. Gloria M. Collins

ASTM

1916 Race Street

Philadelphia, PA 19103

194. William C. Connors

Sundstrand Aviation Operations

Materials Science and

Engineering Department

4747 Harrison Avenue

P.0. Box 7002

Rockford, IL 61125-7002

195. John A. Coppola

Carborundum Company

P.0. Box 156

Niagara Falls, NY 14302

196. Normand D. Corbin

Norton Company

Advanced Ceramics

Goddard Road

Northboro, MA 01532-1545

197. Douglas Corey

Allied-Signal Aerospace

Company

2525 West 190th Street

MS: T52

Torrance, CA 90504-6099
198. Keith P. Costello

Chand/Kare Technical Ceramics

2 Coppage Drive

Worcester, MA 01603-1252

199. Ed L. Courtright

Pacific Northwest Laboratory

MS:K3-59

Richland, WA 99352

200. Anna Cox

Mitchell Market Reports

P.0. Box 23

Monmouth Gwent NP5 4YG

UNITED KINGDOM AIR MAIL

201. Thomas Coyle

Unocal Corporation

Unocal Science \& Technology

Division

376 South Valencia Avenue

Brea, CA 92621

202. Art Cozens

Instron Corporation

3414 Snowden Avenue

Long Beach, CA 90808

203. Robert C. Craft

American Ceramic Society, Inc.

757 Brooksedge Plaza Drive

Hesterville, OH 43081

204. Mark Crawford

New Technology Week

4604 Monterey Drive

Annandale, VA 22003

205. Richard A. Cree

Markets \& Products, Inc.

P.0. Box 14328

Columbus, OH 43214-0328

206. Les Crittenden

Vesuvius McDanel

Box 560

Beaver Falls, PA 15010 
207. William J. Croft

U.S. Army Materials Technology Laboratory 405 Arsenal Street Watertown, MA 02172

208. M. J. Cronin Mechanical Technology, Inc. 968 Albany-Shaker Road Latham, NY 12110

209. Gary M. Crosbie Ford Motor Company 1430 Culver Avenue S-2079, SRL Building Dearborn, MI 48121-4036

210. Floyd W. Crouse, Jr. U.S. Department of Energy Morgantown Energy Technology Center

Collins Ferry Road

P.0. Box 880

Morgantown, WV 26505

211. John Cuccio

Allied-Signal Aerospace Company

Garrett Auxiliary Power Division

P.O. Box 5227, MS:1302-2Q

Phoenix, AZ 85010

212. Raymond Cutler

Ceramatec, Inc.

2425 South 900 West

Salt Lake City, UT 84119

213. Charles D'Angelo

GTE Laboratories, Inc.

40 Sylvan Road

Waltham, MA 02154

214. Stephen C. Danforth

Rutgers University

Ceramic Engineering Department P.0. Box 909

Piscataway, NJ 08855-0909
215. Sankar Das Gupta

Electrofuel Manufacturing Co., Ltd.

9 Hanna Avenue

Toronto Ontario MGK-1W8

CANADA AIR MAIL

216. Charles Davis

Sverdrup Technology, Inc., MSFC

620 Discovery Drive

Huntsville, AL 35806

217. Frank Davis

Allied Signal Aerospace Co.

7550 Lucerne Dr., 203

Middleburg Heights, OH 44130

218. Robert F. Davis

North Carolina State University

Materials Engineering

Department

229 Riddick Laboratory

P.0. Box 7907

Raleigh, NC 27695

219. Thomas DeAngel is

Carborundum Company

Niagara Falls R\&D Center

P.0. Box 832

Niagara Falls, NY 14302

220. George DeBell

Ford Motor Company

Material Systems Reliability

Department

20000 Rotunda Drive

P.0. Box 2053, Room S-2023

Dearborn, MI 48121-2053

221. Michael Deluca

AMP-AKZO

West Lane

Aquebogue, NY 11931

222. Geraid L. DePoorter

Colorado School of Mines

Metallurgical and Materials

Engineering Department Golden, CO 80401 
223. J. F. DeRidder

Omni Electro Motive, Inc., 12 Seely Hill Road

Newfield, NY 14867

224. Nick C. Dellow

Materials Technology

Publications

40 Sotheron Road

Watford Herts WDI 2QA

UNITED KINGDOM AIR MAIL

225. L. R. Dharani

University of Missouri-Rolla

224 M.E.

Rolla, MO 65401

226. Douglas A. Dickerson

Union Carbide Specialty

Powders

1555 Main Street

Indianapolis, IN 46224

227. John Dodsworth

Vesuvius Research \& Development

Technical Ceramics Group

Box 560

Beaver Falls, PA 15010

228. B. Dogan

Institut fur Werkstofforschung

GKSS-Forschungszentrum

Geesthacht GmbH

Max-Pl anck-Strasse

D-2054 Geesthacht

GERMANY AIR MAIL

229. Jean-Marie Drapier

FN Moteurs S.A.

Material and Processing

B-4041 Milmort (Herstal)

BELGIUM AIR MAIL

230. Kenneth C. Dreitlein

United Technologies

Research Center

Silver Lane

East Hartford, СT 06108
231. Robin A.L. Drew

McGill University

Department of Mining and

Metallurgical Engineering

3450 University Street

Montreal Quebec H3A 2A7

CANADA AIR MAIL

232. Winston H. Duckworth

BCL

Columbus Division

505 King Avenue

Columbus, OH 43201-2693

233. Edmund M. Dunn

Texel Company

6 Third Street

Lexington, MA 02173

234. Bill Durako

Sundstrand Aviation Operations

Department 789-6

4747 Harrison Avenue

P.0. Box 7002

Rockford, IL 61125-7002

235. Ernest J. Duwe11

212 Elm Street

Hudson, MI 54016

236. Chuck J. Dziedzic

Coors Ceramics Company

Structural Products Group

17750 West 32nd Avenue

Golden, CO 80401

237. Robert J. Eagan

Sandia National Laboratories

Engineered Materials \&.

Processes Center

Org 1700

P.0. Box 5800

Albuquerque, NM 87185-5800

238. Jeffrey Eagleson

Lanxide Corporation

1001 Connecticut Avenue, N.W. Washington, DC 20036 
239. Harry E. Eaton United Technologies Corporation Research Center

Silver Lane

East Hartford, CT 06108

240. Harvill C. Eaton

Louistana State University

Office of Research and Economic Development

240 Thomas Boyd Hall

Baton Rouge, LA 70803

241. Christopher A. Ebel

Carborundum Company

Technology Division

P.0. Box 337

Niagara Falls, NY 14302

242. J. J. Eberhardt

U.S. Department of Energy

Office of Transportation

Materials

CE-34, Forrestal Building

Washington, DC 20585

243. Jim Edler

Eaton Corporation

26201 Northwestern

Highway

P.0. Box 766

Southfield, MI 48037

244. William A. Ellingson

Argonne National Laboratory

Materials Science \& Technology Division

9700 South Cass Avenue

Argonne, IL 60439

245. Willian S. Ellis

Machined Ceramics

629 N. Graham St.

N. Industrial Park

Bowling Green, KY 42101

246. Glen B. Engle

Nuclear \& Aerospace Materials

Corporation

16716 Martincoit Road

Poway, CA 92064
247. Jeff Epstein

Ceramic Technologies, Inc.

2107 Jamara Lane

Houston, TX 77077

248. Kenneth A. Epstein

Dow Chemical U.S.A.

Ceramics and Advanced

Materials

800 Building

Midland, MI 48667

249. Art Erdemir

Argonne National Laboratory

Materials and Components

Technology Division

9700 South Cass Avenue

Argonne, IL 60439

250. E. M. Erwin

Lubrizol Corporation

1819 East 225th Street

Euclid, OH 44117

251. Kenji Esaki

Toyota Technical Center

U.S.A., Inc.

2000 Town Center, Suite 500

Southfield, MI 48075

252. Jose L. Escalante

Anglo-Mex-Tech. Inc.

3923 H.H. 24th Street

Miami, FL 33142

253. John N. Eust is

U.S. Department of Energy

Industrial Energy Efficiency

Division

CE-221, Forrestal Building

Washington, DC 20585

254. Robert C. Evans

NASA Lewis Research Center

Terrestrial Propulsion Office

21000 Brookpark Road, MS:86-6

Cleveland, OH 44135

255. H. L. Everitt

Kyocera International, Inc.

8611 Balboa Avenue

San Diego, CA 92123 
256. Gordon Q. Evison 332 South Michigan Avenue Suite 1730 Chicago, IL 60604

257. John W. Fairbanks U.S. Department of Energy Advanced Propulsion Division CE-322, Forrestal Building Washington, DC 20585

258. Tim Fawcett

Dow Chemical Company

Central Research, Advanced Ceramics Laboratory 1776 Building

Midl and, MI 48674

259. Robert W. Fawley

Sundstrand Power Systems

Division of Sundstrand Corporation 4400 Ruffin Road

P.0. Box 85757

San Diego, CA 92186-5757

260. John J. Fedorchak GTE Products Corporation Hawes Street

Towanda, PA 18848-0504

261. Jeff T. Fenton Vista Chemical Company 900 Threadneedle Houston, TX 77079

262. Larry Ferrell Babcock \& Wilcox Old Forest Road Lynchburg, VA 24505

263. Raymond R. Fessler BIRL

Industrial Research Lab 1801 Maple Avenue Evanston, IL 60201

264. Michelle Finch E. I. DuPont de Nemours \& Company, Inc.

Experimental Station Information Center E302/301 Wilmington, DE 19898
265. Arthur D. Fine

United Technologies Corporation Pratt \& Whitney Aircraft 400 Main Street

MS: $163-10$

East Hartford, CT 06108

266. Ross F. Firestone

Ross Firestone Company

188 Mary Street

Winnetka, IL 60093-1520

267. Sharon L. Fletcher

Arthur D. Little, Inc.

15 Acorn Park

Cambridge, MA 02140-2390

268. Thomas F. Foltz

Textron Specialty Materials

2 Industrial Avenue

Lowell, MA 01851

269. Renee 6. Ford

Materials and Processing Report

P.0. Box 72

Harrison, NY 10528

270. John Formica

Supermaterials

2020 Lakeside Avenue

Cleveland, OH 44114

271. Jennifer M. Fox

Dyson Refractories Limited

R\&D Laboratory

Owler Bar

Sheffield S17 3BJ

UNITED KINGDOM

AIR MAIL

272. Edwin Frame

Southwest Research Institute

Division 2

P.0. Drawer 28510

San Antonio, TX 78284

273. Armanet Francois

French Scientific Mission

4101 Reservoir Road, N.W.

Washington DC 20007-2176

274. R. G. Frank

Technology Assessment Group

10793 Bentley Pass Lane

Lovel and, $\mathrm{OH} 45140$ 
275. David J. Franus

Forecast International

22 Commerce Road

Newtown, CT 06470

276. Marc R. Freedman

MASA Lewis Research Center

21000 Brookpark Road

MS: 49-3

Cleveland, OH 44135

277. Douglas Freitag

LTV Missiles Division

P.0. Box 650003

MS:WT-21

Dallas, TX 75265

278. Brian R.T. Frost

Argonne National Laboratory

9700 South Cass Avenue

Building 900

Argonne, IL 60439

279. Lawrence R. Frost

Instron Corporation

100 Royall Street

Canton, MA 02021

280. George A. Fryburg

Norton/TRW Ceramics

7A-4 Raymond Avenue

Salem, NH 03079

281. Xiren Fu

Shanghai Institute of Ceramics

Chinese Academy of Sciences

1295 Ding-xi Road

Shanghai 200050

CHIMA AIR MAIL

282. John Gahimer

P.0. Box 1302

Dublin, OH 43017

283. J. P. Gallagher

University of Dayton Research Institute

300 College Park, JPC-250

Dayton, OH 45469-0120

284. Tom Garritano

University of Tennessee

Science Alliance

101 South College

Knoxville, TN 37996-1328

285. Joy A. Garwood

Norton Company

Advanced Ceramics

Goddard Road

Northboro; MA 01532-1545

286. H. Maury Gatewood

Reynolds Metals Company Corporate R\&D

Fourth and Canal Streets

P.0. Box 27003

Richmond, VA 23261

287. L. J. Gauckler

ETH-Zurich

Sonneggstrasse 5

CH-8092 Zurich 8092

SWITZERLAND AIR MAIL

288. Peter A. Gaydos

Battelle Columbus Laboratories

505 King Avenue

Columbus, OH 43201

289. George E. Gazza

U.S. Army Materials Technology Laboratory

Ceramics Research Division

405 Arsenal Street

Hatertown, MA 02172-0001

290. D. Gerster

CEA-DCOM

33 Rue De La Federation

Paris 75015

FRANCE AIR MAIL

291. John Ghinazzi

Coors Technical Ceramics Company

1100 Commerce Park Drive

Oak Ridge, TN 37830 
292. Robert Giddings

General Electric Company

Research Laboratory

P.0. Box 8

Schenectady, wY 12301

293. A. M. Glaeser

University of California Materials Science and Mineral Engineering

Lawrence Berkeley Laboratory

Hearst Mining Building

Berkeley, CA 94720

294. Paul 6lance

Concept Analysis

R\&D

950 Stephenson Highway

Dupont Automotive Development Building

Troy, MI 48007-7013

295. Joseph W. Glatz

Naval Air Propulsion Center

Systems Engineering Division

P.0. Box 7176, PE24

Trenton, NJ 08628

296. H. M. Goldberger

Superior Graphite Company

R\&D

2175 East Broad Street

Columbus, OH 43209

297. Allan E. Goldman

U.S. Graphite, Inc.

907 West Outer Drive

Oak Ridge, TN 37830

298. Stephen T. Gonczy

Allied Signal Research

P.0. Box 5016

Des Plaines, IL 60017

299. Jeffrey M. Gonzales

GTE Products Corporation

Hawes Street

Towanda, PA 18848-0504

300. Robert J. Gottschall

U.S. Department of Energy

ER-131, MS: 6-236

Washington, DC 20545
301. Earl Graham

Cleveland State University

Department of Chemical Engineering

Euclid Avenue at

East 24th Street

Cleveland, OH 44115

302. William A. Graham

Lanxide Corporation

P.0. Box 6077

Newark, DE 19714-6077

303. Robert E. Green, Jr.

Johns Hopkins University

Materials Science and

Engineering Departwent

Baltimore, MD 21218

304. Lance Groseclose

General Motors Corporation

Allison Gas Turbine Division

P.0. Box 420, MS:H-5

Indianapolis, IN 46206

305. Mark F. Gruninger

Union Carbide Corporation

Specialty Pouder Business

1555 Main Street

Indianapolis, IN 46224

306. Ernst Gugel

Cremer Forschungsinstitut GubH\&Co.KG

Oeslauer Strasse 35

D-8633 Roedental 8633

GERMANY

AIR MAIL

307. Donald L. Guile

Corning Glass Norks

SP-DV-1-9

Corning, MY 14831

308. Bimleshwar P. Gupta

Solar Energy Research Institute

Mechanical and Industrial Technology Division

1617 Cole Boulevard

Golden, CO 80401 
309. John P. Gyekenyesi

NASA Lewis Research Center 21000 Brookpark Road, MS:6-1

Cleveland, OH 44135

310. Nabil S. Hakim Detroit Diesel Corporation 13400 West Outer Drive Detroit, MI 48239

311. Phil ip J. Haley General Motors Corporation Vehicular Engineering P.0. Box 420, MS:T12A Indianapolis, IN 46236

312. Judith Hall

Fiber Materials, Inc. Biddeford Industrial Park 5 Morin Street Biddeford, ME 04005

313. Y. Harada

IIT Research Institute Nometallic Materials and Composites

10 West 35th Street Chicago, IL 60616

314. R. A. Harmon

25 Schalren Drive Latham, NY 12110

315. Amy Harmon-Barrett Mart in Marietta Laboratories 1450 South Rolling Road Baltimore, MD 21227

316. Norman H. Harris Hughes Aircraft Company P.0. Box 800520 Saugus, CA 91380-0520

317. Al an Hart Dow Chemical Company Advanced Ceramics Laboratory 1776 Building Midland, MI 48674
318. Pat E. Hart Battelle Pacific Northwest Laboratories Ceramics and Polymers Development Section

P.0. Box 999

Richland, WA 99352

319. Stephen D. Hartl ine Norton Company Advanced Ceramics Goddard Road Northboro, MA 01532-1545

320. Michael H. Haselkorn Caterpillar, Inc.

Engineering Research Materials Technical Center, Building E P.0. Box 1875

Peoria, IL 61656-1875

321. N. B. Havewala

Corning, Inc.

SP-PR-11

Corning, NY 14831

322. John Haygarth

Teledyne WAA Chang Albany

P.0. Box 460

Albany, OR 97321

323. Norman L. Hecht University of Dayton Research Institute 300 College Park

Dayton, OH 45469-0172

324. Peter H. Heitman General Motors Corporation Allison Gas Turbine Division P.O. Box 420, MS:W-5 Indianapol is, IN 46206-0420

325. Robert W. Hendricks

Virginia Polytechnic Institute and State University Materials Engineering Department 210 Holden Hall B1acksburg, VA 24061-0237 
326. Hynne Henley Hertel Cutting Technologies, Inc. 1000 Clearview Court Oak Ridge, TN 37830

327. Thomas L. Henson GTE Products Corporation Chemical \& Metallurgical Division

Hawes Street

Towanda, PA 18848

328. Thomas P. Herbell

NASA Lewis Research Center

21000 Brookpark Road

MS: 49-3

Clevel and, OH 44135

329. Marlene Heroux

Rolls-Royce, Inc.

2849 Paces Ferry Road

Suite 450

Atlanta, 6A 30339-3769

330. Robert L. Hershey

Science Management Corporation

1255 New Hampshire Ave., N.W.

Suite 1033

Washington, DC 20036

331. Hendrik Heystek

Bureau of Mines

Tuscaloosa Research Center

P.O. Box L

University, AL 35486

332. Wallace C. Higgins

Norwal Uni imited

P.0. Box 1258

Alfred, NY 14802

333. Robert V. Hillery

GE Aircraft Engines

One Neumann Way, M.D. H85

Cincinnati, OH 45215

334. Arthur Hindman

Instron Corporation

100 Royall Street

Canton, MA 02021
335. Jon Hines

American Ceramic Society, Inc.

757 Brooksedge Plaza Drive

Westerville, OH 43081-6136

336. Hans Erich Hintermann

CSEM

Materials and Micromechanics Division

Rue Breguet 2

Neuchatel-2000

SWITZERLAND AIR MAIL

337. Shinichi Hirano

Mazda R\&D of North

America, Inc.

1203 Woodridge Avenue

Ann Arbor, MI 48105

338. Tommy Hiraoka

NGK Locke, Inc.

1000 Town Center

Southfield, MI 48075

339. John M. Hobday

U.S. Department of Energy

Morgantown Energy Technology Center

Collins Ferry Road

P.0. Box 880

Morgantown, WV 26507

340. Greg Hoenes

Vista Chemical Company

900 Threadneedle

P.O. Box 19029

Houston, TX 77079-2990

341. Clarence Hoenig

Lawrence Livermore National Laboratory

P.0. Box 808, Maif Code L-369

Livermore, CA 94550

342. Thomas Hollstein

Fraunhofer-Institut fur Werkstoffmechanik IMM

Wohlerstrabe 11

D-7800 Freiburg

GERMANY AIR MAIL 
343. Richard Holt

National Research Council of Canada

Structures and Materials Laboratory

Ottawa Ontario KIA OR6

CANADA AIR MAIL

344. Joseph Homeny

University of Illinois

Department of Materials Science and Engineering

105 South Goodwin Avenue

Ceramics Building

Urbana, IL 61801

345. A. T. Hopper

Battelle Columbus

Laboratories

Metals and Ceramics Department

505 King Avenue

Columbus, OH 43201-2693

346. Michael Horgan

Materials Engineering Magazine

1100 Superior Avenue

Cleveland, $\mathrm{OH} 44114$

347. Woodie Howe

Coors Technical Ceramics

Company

1100 Commerce Park Drive

Oak Ridge, TN 37830

348. Stephen M. Hsu

National Institute of

Standards and Technology

Gaithersburg, MD 20899

349. Hann S. Huang

Argonne National Laboratory

9700 South Cass Avenue

Argonne, IL 60439-4815

350. Gene Huber

Precision Ferrites \& Ceramics

5576 Corporate Drive

Cypress, CA 90630

351. M. L. Huckabee

GTE Laboratories, Inc.

40 Sylvan Road

Wal tham, MA 02254
352. Harold A. Huckins

Princeton Advanced

Technology, Inc.

56 Finley Road

Princeton, NJ 08540

353. Fred R. Huettic

Advanced Magnetics, Inc.

45 Corey Lane

Mendham, NJ 07945

354. Bill Huffman

Zircar

110 North Main Street

Florida, NY 10921

355. Brian K. Humphrey

Lubrizol Petroleum

Chemicals Co.

3000 Town Center, Suite 1340

Southfield, MI 48075-1201

356. Robert M. Humrick

Dylon Ceramic Technologies

3100 Edgehill Road

Cleveland Heights, OH 44118

357. Lorretta Inglehart

National Science Foundation

Division of Materials Research

1800 "G" Street, N.W.,

Room 408

Washington, DC 20550

358. Michael S. Inoue

Kyocera International, Inc.

KII Library

8611 Balboa Avenue

San Diego, CA 92123-1580

359. Osama Jadaan

University of Hisconsin-

Platteville

General Engineering Division

1 University Plaza

Platteville, WI 53818

360. Curtis A. Johnson

General Electric Company

Corporate R\&D

Room MB-187

P.0. Box 8

Schenectady, NY 12301 
361. Sylvia Johnson

SRI International

333 Ravenswood Avenue

Menlo Park, CA 94025

362. Thomas A. Johnson Lanxide Corporation

1300 Marrows Road

P.0. Box 6077

Newark, OE 19714-6077

363. U. S. Johnson

Indiana University

One City Centre, Suite 200

Bloomington, IN 47405

364. Jill E. Jonkouski

U.S. Department of Energy

9800 South Cass Avenue

Argonne, IL 60439-4899

365. L. A. Joo

Great Lakes Research Corporation

P.0. Box 1031

El izabethton, TN 37643

366. A. D. Joseph

SPX Corporation

700 Terrace Point

Muskegon, MI 49443

367. Adam Jostsons

Australian Nuclear Science \& Technology Organization

Lucas Heights Research Laboratories

New Illawarra Road

Lucas Heights New South Wales

AUSTRALIA AIR MAIL

368. Matthew K. Juneau

Ethyl Corporation

451 Florida Street

Baton Rouge, LA 70801

369. Hartmut Kainer

Didier-Werke AG

Anlagentechnik Wiesbaden

Abraham-Lincoln-Str. 16

D-62 Wiesbaden

GERMANY AIR MAIL
370. Tom Kalamasz

Norton/TRW Ceramics

7A-4 Raymond Avenue

Salem, NH 03079

371. Lyle R. Kallenbach

Phillips Petroleum Company

RED

Mail Drop:123AL

Bartiesvilie, OK 74004

372. Nick Kamiya

Kyocera Industrial Ceramics Corporation

2700 River Road

Des Plaines, IL 60018

373. Roy Kamo

Adiabatics, Inc.

3385 Commerce Park Drive

Columbus, IN 47201

374. S. Kang

GTE Laboratories, Inc.

40 Sylvan Road

Waltham, MA 02254

375. Chih-Chun Kao

Industrial Technology Research Institute

Materials Research

Laboratories

195 Chung-Hsing Road, Sec. 4

Chutung Hsinchu 31015 R.O.C.

TAIWAN AIR MAIL

376. Keith R. Karasek

All ied-Signal, Inc.

Engineered Materials Research Center

50 East Algonquin Road

P.0. Box 5016

Des Plaines, IL 60017-5016

377. Robert E. Kassel

Ceradyne, Inc.

3169 Redhill Avenue

Costa Mesa, CA 92626

378. Allan Katz

Uright Laboratory

Metals and Ceramics Division

HL/MLLM

Wright-Patterson AFB, OH 45433 
379. R. Nathan Katz

Worcester Polytechnic Inst itute

Dept. of Mechanical Engineering

100 Institute Road

Worcester, MA 01609

380. Ted Kawaguchi

Tokai Carbon America, Inc.

375 Park Avenue, Suite 3802

New York, NY 10152

381. Noritsugu Kawashima

TOSHIBA Corporation

Mechanical Engineering Laboratory

4-1 Ukishima-Cho

Kawasaki-Ku Kawasaki 210

JAPAN AIR MAIL

382. Lisa Kempfer

Penton Publishing

Materials Engineering

1100 Superior Avenue

Clevel and, $\mathrm{OH}$ 44114-2543

383. Frederick L. Kennard, III

General Motors Corporation

AC Rochester

Department 32-24, EB

1300 North Dort Highway

Flint, MI 48556

384. David 0. Kennedy

Lester B. Knight Cast

Metals Inc.

549 West Randolph Street

Chicago, IL 60661

385. George Keros

Photon Physics

3175 Penobscot Building

Detroit, MI 48226

386. Pramod K. Khandelwal

General Motors Corporation

Allison Gas Turbine Division

P.0. Box 420, MS:W05

Indianapolis, IN 46206
387. Jim R. Kidwell

Allied-Signal Aerospace Company

Garrett Auxiliary Power Division

P.0. Box 5227

Phoenix, AZ 85010

388. Han J. Kim

GTE Laboratories, Inc.

40 Sylvan Road

Naltham, MA 02254

389. Shin Kim

Korea Institute of Machinery \& Metals

66 Sangnam-dong, Changwon

Kyungnam 641-010

KOREA AIR MAIL

390. H. C. King

Mack Truck, Z-41

1999 Pennsylvania Avenue

Hagerstown, MD 21740

391. Carol Kirkpatrick

MSE, Ine.

CDIf Technical Library

P.0. Box 3767

Butte, MT 59702

392. Tony Kirn

Caterpillar, Inc.

Defense Products Department, JB7

Peoria, IL 61629

393. James D. Kiser

MASA Lewis Research Center

21000 Brookpark Road, MS:49-3

Clevel and, OH 44135

394. Max Klein

Gas Research Institute

Thermodynamics

8600 West Bryn Mawr Avenue

Chicago, IL 60631

395. Richard N. Kleiner

Coors Ceramics Company

4545 McIntyre Street

Golden, CO 80403 
396. Stanley J. K1 ima

NASA Lewis Research Center

21000 Brookpark Road

MS: 6-1

Cleveland, $\mathrm{OH} 44135$

397. Chris E. Knapp

Norton Advanced Ceramics of Canada Ltd.

8001 Daly Street

Niagara Falls, Ontario L2G 652 CANADA AIR MAIL

398. Albert S. Kobayashi

University of Washington

Mechanical Engineering

Department

MS:FU10

Seattle, WA 98195

399. Shigeki Kobayashi

Toyota Central Research Labs, Inc.

Nagakute Aichi 480-11

JAPAN AIR MAIL

400. Richard A. Kole

Z-Tech Corporation

8 Dow Road

Bow, NH 03304

401. E. Kostiner

University of Connecticut

Chemistry Department, U-60

Storrs, CT 06269-3060

402. Kenneth A. Kovaly

Technical Insights, Inc.

P.0. Box 1304

Fort Lee, NJ 07024-9967

403. Ralph G. Kraft

Spraying Systems Company

North Avenue at Schmale Road

Wheaton, IL 60189-7900

404. Saunders B. Kramer

U.S. Department of Energy

Advanced Propulsion Division

CE-322, Forrestal Building

Washington, DC 20585
405. Arthur Kranish

Trends Pubtishing, Inc.

1079 National Press Building

Washington, DC 20045

406. A. S. Krieger

Radiation Science, Inc.

P.0. Box 293

Belmont, MA 02178

407. Pieter Krijgsman

Ceramic Design International Holding B.V.

P.0. Box 68

Hattem 8050-AB

THE NETHERLANDS

AIR MAIL

408. Waltraud M. Kriven

University of Illinois

Materials Science and

Engineering Department

105 South Goodwin Avenue

Urbana, IL 61801

409. Edward J. Kubel, Jr.

ASM International Advanced

Materials \& Processes

Materials Park, OH 44073

410. Dave Kupperman

Argonne National Laboratory

9700 South Cass Avenue

Argonne, IL 60439

411. Oh-Hun Kwon

Morton Company

Advanced Ceramics

Goddard Road

Northboro, MA 01532-1545

412. H. J. Lackey

Georgia Institute of Technology

Materials Science and

Technology

Atlanta, GA 30332

413. Jai Lala

Tenmat Ltd.

40 Somers Road

Rugby Warwickshire CV22 7DH

ENGLAND AIR MAIL 
414. Hari S. Lamba General Motors Corporation Electro-Motive Division 9301 West 55th Street LaGrange, IL 60525

415. Richard L. Landingham Laurence Livermore National Laboratory

Ceramics, Corrosion, and Thermochemistry

P.0. Box 808, L-369

Livermore, CA 94550

416. Charles J. Landry

Chand Kare Technical Ceramics

712 Flat Hill Road

Lumenburg, MA 01462

417. Manfred W. Langer

Volkswagen AG

Material Technology

3180 Wolfsburg 1

GERMANY AIR MAIL

418. James Lankford

Southwest Research Institute

Department of Materials Sciences

6220 Culebra Road

San Antonio, TX 78228-0510

419. Stanley B. Lasday

Business News Publishing Co.

Manor Oak One

1910 Cochran Road, Suite 630

Pittsburgh, PA 15220

420. Mark S. Laser

Solar Turbines, Inc.

2211 Erie Street

San Diego, CA 92110

421. S. K. Lau

Carborundum Company

Technology Division

P.0. Box 832, B-100

Niagara Falls, NY 14302

422. Edward A. Lauder

Advanced Composite Materials

Corporation

1525 South Buncombe Road

Greer, SC 29651-9208
423. J. Laurence Lauderdale Babcock \& Hilcox

Contract Research Division 1850 "K" Street, Suite 950 Washington, DC 20006

424. Harry A. Lawler

Carborundum Company

Technology Division

P.0. Box 832

Niagara Falls, NY 14302

425. Jean F. LeCostaouec

Textron Speciality Materials

2 Industrial Avenue

Lowe11, MA 01851

426. Benson P. Lee

Interscience, Inc.

9718 Lake Shore Boulevard

Cleveland, $\mathrm{OH} 44108$

427. Burtrand I. Lee

Clemson University

Department of Ceramic

Engineering

01 in Hall

Clemson, SC 29634-0907

428. June-Gunn Lee

KIST

Structural Ceramic Lab

P.0. Box 131, Cheong-Ryang

Seoul 130-650

KOREA AIR MAIL

429. Ran-Rong Lee

Ceramics Process Systems

Corporation

155 Fortune Boulevard

Milford, MA 01757

430. Stan Levine

MASA Lewis Research Center

21000 Brookpark Road

MS: 49-3

Cleveland, OH 44135

431. Alan V. Levy

Lawrence Berkeley Laboratory

One Cyclotron Road, MS:62-203 Berkeley, CA 94720 
432. Ai-Kang Li

Materials Research Laboratories, ITRI 195-5 Chung-Hsing Road, Sec. 4 Chutung Hsinchu 31015 R.O.C. TAIWAN AIR MAIL

433. Winston H. Liang Hong Kong Industrial Technology Centre Co. Ltd.

78 Tat Chee Avenue

4/F, HKPC Building Howloon

HONG KONG AIR MAIL

434. Robert Licht

Norton Company

Advanced Ceramics

Goddard Road

Northboro, MA 01532-1545

435. E. Lilley

Norton Company

Advanced Ceramics

Goddard Road

Northboro, MA 01532-1545

436. Laura J. Lindberg

Allied-Signal Aerospace Company

Garrett Fluid Systems Division 1300 West Warner

MS: 93-901-1207-4TT

P.0. Box 22200

Tempe, AZ 85284-2200

437. Leonard C. Lindgren

General Motors Corporation

Allison Gas Turbine Division

P.0. Box 420, Speed Code:T-20A

Indianapol is, IN 46206-0420

438. Hans A. Lindner

Cremer Forschungsinstitut GmbH\&CO.KG

Oeslauer Strasse 35

D-8633 Rodental 8866

GERMANY AIR MAIL
439. Ronald E. Loehman

Sandia National Laboratories

Chemistry \& Ceramics

Department 1840

P.0. Box 5800

Aibuquerque, NM 87185

440. Jeffrey C. Logas

Winona State University

Composite Materials

Engineering

115 Pasteur Hall

Winona, MN 55987

441. Bill Long

Babcock \& Wilcox

P.O. Box 11165

Lynchburg, VA 24506

442. William D. Long

Wacker Chemicais (USA), Inc.

ESK Engineered Ceramics

50 Locust Avenue

New Canaan, CT 06840

443. L. A. Lott

EG\&G Idaho, Inc.

Idaho National Engineering Laboratory

P.0. Box 1625

Idaho Falls, ID 83415-2209

444. Raouf 0. Loutfy

MER Corporation

7960 South Kolb Road

Tucson, AZ 85706

445. Gordon R. Love

A] uminum Company of America

Alcoa Technical Center

Alcoa Center, PA 15069

446. Lydia Luckevich

Ortech International

2395 Speakman Drive

Mississauga Ontario L5K 183

CANADA AIR MAIL 
447. James W. MacBeth

Carborundum Company

Structural Ceramics Division

P.0. Box 1054

Niagara Falls, NY 14302

448. H. MacLaren

General Electric Company

Thomson Laboratory, Materials

Engineering 36807

1000 Western Avenue

Lynn, MA 01910

449. George Maczura

Aluminum Company of America

Industrial Chemicals Division

670 One Allegheny Square

Pittsburgh, PA 15212

450. David Maginnis

Tinker AFB

OC-ALC/LIIRE

Tinker AFB OK 73145-5989

451. Frank Maginnis

Aspen Research, Inc.

220 Industrial Boulevard

Moore, OK 73160

452. Tai-il Mah

Universal Energy Systems, Inc.

Ceramics and Composites Research

4401 Dayton-Xenia Road

Dayton, OH 45432

453. Kenneth M. Maillar

Barbour Stockwell Company

83 Linskey May

Cambridge, MA 02142

454. Lorenzo Majno

Instron Corporation

100 Royall Street

Canton, MA 02021

455. S. G. Malghan

National Institute of Standards and Technology

I-270 \& Clopper Road

Gaithersburg, MD 20899
456. Lars Malmrup

United Turbine AB

Box 13027

Malmo S-200 44

SWEDEN AIR MAIL

457. John Mangels

Ceradyne, Inc.

3169 Redhill Avenue

Costa Mesa, CA 92626

458. Russell V. Mann

Matec Applied Sciences, Inc.

75 South Street

Hopkinton, MA 01748

459. Hilliam R. Manning

Champion Aviation Products

Division

old Norris Road

P.0. Box 686

Liberty, SC 29657

460. Ken Marnoch

Amercom, Inc.

8928 Fullbright Avenue

Chatsworth, CA 91311

461. Robert A. Marra

Aluminum Company of America

Alcoa Technical Center

Advanced Ceramics Center - E

Alcoa Center, PA 15069

462. Chauncey L. Martin

3M Company

3M Center, Building 60-1N-01

St. Paul, IN 55144

463. Steven C. Martin

Advanced Refractory

Technologies, Inc.

699 Hertel Avenue

Buffalo, NY 14207

464. Kelly J. Mather

Williams International

Corporation

2280 West Maple Road

P.0. Box 200

Walled Lake, MI 48088 
465. James $P$. Mathers

3M Company

3M Center

Building 201-3N-06

St. PauT, MN 55144

466. Marshall Mayer

Instron Corporation

3815 Presidential Parkway, Suite 100

Atlanta, GA 30340

467. Ron Mayville

Arthur D. Little, Inc.

15-163 Acorn Park

Cambridge, MA 02140

468. F. N. Mazadarany

General Electric Company

Research Laboratory

Building K-1, Room MB-159

P.0. Box 8

Schenectady, NY 12301

469. James W. McCauley

Alfred University

NYS College of Ceramics

Binns-Merrill Hall

Alfred, NY 14802

470. Carolyn McCormick

Allied-Signal Aerospace Company

Garrett Auxiliary Power Division

Bldg. 1303-206

P.O. Box 5227, MS: $9317-2$

Phoenix, AZ 85010

471. Louis R. McCreight

2763 San Ramon Drive

Rancho Palos Verdes, CA 90274

472. Col in F. McDonald

McDonald Thermal Engineering

1730 Castellana Road

La Jolla, CA 92037

473. B. J. McEntire

Norton Company, TRW Ceramics

Goddard Road

Northboro, MA 01532-1545
474. Chuck McFadden

Coors Ceramics Company

600 9th Street

Golden, CO 80401

475. Henry McFadden

Magnetic Bearings, Inc.

Engineering Library

609 Rock Road

Radford, VA 24141

476. Thomas D. McGee

Iowa State University

Materials Science and

Engineering Department

110 Engineering Annex

Ames, IA 50011

477. Carol McGill

Corning Inc.

Sullivan Park, FR-02-08

Corning, NY 14831

478. T. C. MeLaren

Cameron Forged Products Company

P.O. Box 1212

Houston, TX 77251-1212

479. James MeLaughl in

Sundstrand Power Systems

4400 Ruffin Road

P.O. Box 85757

San Diego, CA 92186-5757

480. Arthur F. McLean

6225 North Camino Almonte

Tucson, AZ 85718

481. Matt McMonigle

U.S. Department of Energy

Improved Energy Productivity Division

Forrestal Building, CE-231

Washington, DC 20585

482. Dennis McMurtry

EGRG Idaho, Inc.

Idaho National Engineering Laboratory

P.0. Box 1625

Idaho Falls, ID 83415 
483. D. B. Meadowcroft

National Power Technology and Environmental Centre

Kelvin Avenue

Leatherhead Surrey

KT22 7SE

ENGLAND AIR MAIL

484. Jo Meglen

11004 Birdfoot Court

Reston, VA 22091

485. Pankaj K. Mehrotra

Kennametal, Inc.

P.0. Box 639

Greensburg, PA 15601

486. Joseph J. Meindl

Reynolds International, Inc.

6603 Hest Broad Street

P.0. Box 27002

Richmond, VA 23261-7003

487. Michael D. Meiser

Allied-Signal Aerospace Company

Garrett Ceramic Components

Division

19800 South Van Ness Avenue

Torrance, CA 90509

488. George Messenger

National Research Council of Canada

Engine Laboratory

Building M-7

Ottawa Ontario K1A OR6

CANADA AIR MAIL

489. D. Messier

U.S. Army Materials Technology Laboratory

SLCMT-EMC

405 Arsenal Street

Watertown, 02172-0001

490. Gary L. Messing

Pennsylvania State University

Ceramic Science and Engineering Department

119 Steidle Building

University Park, PA 16802
491. Arthur 6. Metcalfe

Arthur 6. Metcalfe and Associates, Inc.

2108 East 24th Street

Mational City, CA 91950

492. R. Metselaar

Eindhoven University

Centre for Technical Ceramics

P.0. Box 513

Eindhoven 5600 MB

THE NETHERLANDS

AIR MAIL

493. Nancy S. Meyers

U.S. Department of Energy

Transportation Technologies

CE-30, Forrestal Building 6B-094

Washington, DC 20585

494. David J. Michael

Harbison-Malker Refractories Company

P.0. Box 98037

Pittsburgh, PA 15227

495. Ken Michaels

Chrysier Motors Corporation

Ceramics Development Metallurgical Processes

P.0. Box 1118, CIMS:418-17-09

Detroit, MI 48288

496. Bernd Michel

Institute of Mechanics

Fracture and Micromechanics Department

P.0. Box 408

D-9010 Chemnitz

GERNANY AIR MAIL

497. David E. Miles

Commission of the European Communities

rue de la Loi, 200

B-1049 Brusseis

BELGIUNA AIR MAIL

498. John V. Milewski

Superkinetics, Inc.

P.0. Box 8029

Santa Fe, MM 87504 
499. Carl E. Miller

AC Rochester

1300 North Dort Highway, MS:32-31

Engineering Building B

Flint, MI 48556

500. Mike Miller

McGraw-Hill Aviation Week

Performance Materials

1156 15th Street, N.W.

Washington, DC 20005

501. Charles H. Miller, Jr.

Centorr Furnaces/Vacuum Industries

542 Amherst Street

Nashua, NH 03063

502. R. Mininni

Enichem America

2000 Cornwall Road

Monmouth Junction, NJ 08852

503. Michele V. Mitchell

Allied-Signal Aerospace Company

Garrett Ceramic Components Division

19800 South Van Ness Avenue

Torrance, CA 90501-1149

504. Howard Mizuhara

GTE - NESGO

477 Harbor Boulevard

Belmont, CA 94002

505. Helen Moeller

Babcock \& Wilcox

P.0. Box 11165

Lynchburg, VA 24506-1165

506. Francois R. Mollard

Metalworking Technology, Inc.

1450 Scalp Avenue

Johnstown, PA 15904

507. Phil Mooney

Panametrics

NDE Division

221 Crescent Street

Waltham, MA 02254
508. Thomas Morel

Ricardo North America

645 Blackhawk Drive

Hestmont, IL 60559

509. Geoffrey P. Morris

3M Company

3M Traffic Control Materials Division

Bldg. 209-BW-10, 3M Center

St. Paul, . .NW 55144-1000

510. Jay A. Morrison

Rolls-Royce, Inc.

Engineering and Information Center, Overlook 1

2849 Paces Ferry Road, Suite 450

Atlanta, 6A 30339-3769

511. Joel P. Moskowitz

Ceradyne, Inc.

3169 Redhill Avenue

Costa Mesa, CA 92626

512. Brij Moudgil

University of Florida

Material Science and Engineering

Gainesville, FL 32611

513. Christoph J. Mueller

Sprechsaal Publishing Group

P.0. Box 2962, Mauer 2 D-8630 Coburg

GERMANY AIR MAIL

514. Thomas K. Mullan

Vapor Technologies Inc.

345 Route 17 South

Upper Saddle River, NJ 07458

515. M. K. Murthy

MKM Consultants International

10 Avoca Avenue, Unit 1906

Toronto Ontario M4T 2B7

CANADA AIR MAIL

516. Solomon Musikant

TransCon Technologies, Inc.

Materials Science \& Engineering 1508 Waynesboro Road

Paoli, PA 19301 
517. David L. Mustoe

Custom Technical Ceramics

8041 Hest I-70 Service Road, Unit 6

Arvada, CO 80002

518. Curtis V. Nakaishi

U.S. Department of Energy

Morgantown Energy Technology Center

Collins Ferry Road

P.0. Box 880

Morgantown, WN 26507-0880

519. Yoshio Nakamura

Faicera Research Institute

2-5-8 Hiyakunin-cho Shinjuku-Ko

Tokyo

JAPAN AIR MAIL

520. K. S. Narasimhan

Hoeganaes Corporation

River Road

Riverton, NJ 08077

521. Samuel Natansohn

GTE Laboratories, Inc.

40 Sylvan Road

Waltham, MA 02254

522. Robert Naum

Applied Resources, Inc.

P.0. Box 241

Pittsford, NY 14534

523. Malcolm Naylor

Cummins Engine Company, Inc.

P.0. Box 3005, Mait Code 50183

Columbus, IN 47202-3005

524. Jeffrey Neil

GTE Laboratories, Inc.

40 Sylvan Road

Waltham, MA 02254

525. Fred A. Nichols

Argonne National Laboratory

9700 South Cass Avenue

MCT - Building 212

Argonne, IL 60439
526. H. Nickel

Furschungszentrum Jüelich (KFA)

P.0. Box 1913

Jüel ich 1-5170 BRD NRW

GERMANY AIR MAIL

527. Dale E. Niesz

Rutgers University

Center for Ceramic Research

P.0. Box 909

Piscataway, NJ 08855-0909

528. David M. Nissley

United Technologies Corporation

Pratt \& Whitney Aircraft

400 Main Street, MS:163-10

East Hartford, CT 06108

529. Richard D. Nixdorf

ReMaxCo Technologies, Inc.

11317 Snyder Road

Knoxville, TN 37932

530. Bernard North

Kennametal, Inc.

P.0. Box 639

Greensburg, PA 15601

531. Bruce E. Novich

Ceranics Process Systems

Corporation

155 Fortune Boulevard

Milford, MA 01757

532. Daniel Oblas

GTE Laboratories, Inc.

40 Sylvan Road

Waltham, MA 02254

533. Don Ohanehi

Magnetic Bearings, Inc.

1908 Sussex Road

Blacksburg, VA 24060

534. Robert Orenstein

General Electric Company

55-112, River Road

Schenectady, NY 12345 
535. Norb Osborn

Aerodyne Dallas

151 Regal Row,

Suite 120

Dallas, TX 75247

536. A. M. Paddick

BP International Limited

BP Research Centre, Main Library

Chertsey Road

Sunbury-on-Thames

Middlesex TW16 7LN

UNITED KINGDOM

AIR MAIL

537. Russell J. Page

Kanthal-Artcor

3001 Redhill Avenue, II-109

Costa Mesa, CA 92705

538. Richard Palicka

Cercom, Inc.

1960 Watson Way

Vista, CA 92083

539. Muktesh Paliwal

GTE Products Corporation

Hawes Street

Towanda, PA 18848

540. Joseph E. Palko

General Electric Company

55-113, River Road

Schenectady, NY 12345

541. Hayne Palmour, III

North Carolina State University

Materials Science and Engineering Dept.

Raleigh, NC 27605-7905

542. Joseph N. Panzarino

Norton Company

Advanced Ceramics

Goddard Road

Northboro, MA 01532-1545

543. Pellegrino Papa

Corning Inc.

MP-WX-02-1

Corning, NY 14831
544. E. Beth Pardue

Technology for Energy

Corporation

One Energy Center

P.0. Box 22996

Knoxville, TN 37933-0996

545. Soon C. Park

3H Company

3M Center

Building 142-4N-02

P.0. Box 2963

St. Pau1, MN 55144

546. Hartmut Paschke

Schott Glaswerke

Christoph-Dorner-Strasse 29

D-8300 Landshut

GERMANY AIR MAIL

547. Marina R. Pascucci

GTE Laboratories, Inc.

40 Sylvan Road

Waltham, MA 02254

548. James W. Patten

Cumins Engine

Company, Inc.

Materials Engineering

P.0. Box 3005, Mail

Code 50183

Columbus, IN 47202-3005

549. Robert A. Penty

Eastman Kodak Company

KAD/073 - 35612

901 Elmgrove Road

Rochester, NY 14653

550. Robert W. Pepper

Textron Specialty Materials

2 Industrial Avenue

Lowe11, MA 01851

551. Peter Perdue

Detroit Diesel Corporation

Research Advanced Development Group

13400 West Outer Drive, Speed Code A-07

Detroit, MI 48239-4001 
552. Bruce Peters

Dow Chemical Company

Butlding 52

Midl and, MI 48667

553. John J. Petrovic

Los Al amos National Laboratory

Group MST-4, MS:6771

Los Alamos, NM 87545

554. Frederick S. Pettit

University of Pittsburgh

Pittsburgh, PA 15261

555. Ben A. Phillips

Phillips Engineering Company

721 Pleasant Street

St. Joseph, MI 49085

556. Richard C. Phoenix

Ohmtek, Inc.

2160 Liberty Drive

Niagara Falls, NY 14302

557. Bruce J. Pletka

Michigan Technological University

Metallurgical and Materials

Engineering Department

Houghton, MI 49931

558. John P. Pollinger

Garrett Ceramic Components

19800 Van Ness Avenue

Torrance, CA 90501

559. P. Popper

High Technology Ceramics International Journal

22 Pembroke Drive

Hestlands Newcastle-under-Lyme Staffs ST5 2JN

ENGLAND AIR MAIL

560. F. Porz

Universitat Karlsruhe

Institut fur Keramik Im Maschinendau

Postfach 6980

D-7500 Karlsruhe GERMANY

AIR MAIL
561. Harry L. Potma

Royal Netherlands Embassy

Science and Technology

4200 Linnean Avenue, N.W.

Washington, DC 20008

562. Bob R. Powell

General Motors Research

Laboratories

Metall luray Department

30500 Mound Road

Box 9055

Warren, MI 48090-9055

563. Stephen C. Pred

ICD Group, Inc.

1100 Valley Brook Avenue

Lyndhurst, NJ 07071

564. Karl M. Prewo

United Technologies Research Center

411 Silver Lane

MS: 24

East Hartford, CT 06108

565. Peter E. Price

Industrial Materials Technology, Inc.

P.0. Box 9565

Andover, MA 01810

566. Joseph M. Proud

GTE Laboratories, Inc.

Materials Science Laboratory

40 Sylvan Road

Naltham, MA 02254

567. Vimal K. Pujari

Norton Company

Advanced Ceramics

Goddard Road

Northboro, MA 01532-1545

568. George Quinn

National Institute of

Standards and Technology

Ceramics Division, Bldg. 223

Gaithersburg, ND 20899 
569. Ramas V. Raman

Ceracon, Inc.

1101 North Market Boulevard, Suite 9

Sacramento, CA 95834

570. Charles F. Rapp

Owens Corning Fiberglass

2790 Columbus Road

Granville, OH 43023-1200

571. Dennis W. Readey

Colorado School of Mines

Department of Metallurgy and Materials Engineering

Golden, CO 80401

572. Wilfred J. Rebello

PAR Enterprises, Inc.

12601 Clifton Hunt Lane

Clifton, VA 22024

573. Harold Rechter

Chicago Fire Brick Company R\&D

7531 South Ashland Avenue

Chicago, IL 60620

574. Robert R. Reeber

U.S. Army Research Office

P.0. Box 12211

Research Triangle Park, NC 27709

575. K. L. Reifsnider

Virginia Polytechnic Institute and State University

Department of Engineering Science and Mechanics

Blacksburg, VA 24061

576. Paul E. Rempes

McDonnell Douglass Missle Systems Company

P.0. Box 516,

Mail Code: 1066086

St. Louis, MO 63166-0516

577. Gopal S. Revankar

John Deere Company

Metals Research

3300 River Drive

Moline, IL 61265
578. K. T. Rhee

Rutgers University

Mechanical Engineering

P.0. Box 909

Piscataway, NJ 08854

579. James Rhodes

Advanced Composite Materials

Corporation

1525 South Buncombe Road

Greer, SC 29651

580. Roy H. Rice

H. R. Grace and Company

7379 Route 32

Columbia, MD 21044

581. David W. Richerson

2093 East Delmont Drive

Salt Lake City, UT 84117

582. Tomas Richter

J. H. France Refractories

1944 Clarence Road

Snow Shoe, PA 16874

583. Michel Rigaud

Ecole Polytechnique

Campus Universite De Montreal

P.0. Box 6079, Station A

Montreal, P.Q Quebec H3C $3 A 7$

CANADA AIR MAIL

584. R. E. Riman

Rutgers University

Ceramics Engineering

Department

P.0. Box 909

Piscataway, NJ 08855-0909

585. Barry Ringstrom

Superior Graphite Company

P.0. Box 2373

Smyrna, GA 30081

586. John E. Ritter

University of Massachusetts

Mechanical Engineering Department

Amherst, MA 01003 
587. Frank L. Roberge

Altied-Signal Aerospace Company

Garrett Auxiliary Power Division

P.0. Box 5227

Phoenix, AZ 85010

588. W. Eric Roberts

Advanced Ceramic

Technology, Inc.

990 "F" Enterprise Street

Orange, CA 92667

589. Martha Rohr

U.S. Department of Energy

DOE Oak Ridge Field Office

Building 4500N

P.0. Box 2008, MS: 6269

Oak Ridge, TN 37831-6269

590. Y. G. Roman

THO TPD Keramick

P.0. Box 595

Einhoven 5600 AN

HOLLAND AIR MAIL

591. Mark D. Roos

Carborundum Company

P.0. Box 156

Niagara Falls, NY 14302

592. Michael Rossetti

Arthur D. Littie, Inc.

15 Acorn Park

Cambridge, MA 01240

593. Barry R. Rossing Lanxide Corporation

1300 Marrows Road

Newark, DE 19714-6077

594. Steven L. Rotz

Lubrizol Corporation

29400 Lakeland Boulevard

Wickliffe, OH 44092

595. Bruce Rubinger

Global Competitiveness, Inc.

One Devonshire Place, Suite 1011

Boston, MA 02109
596. Robert Ruh

Wright Laboratory

WL/MLLM

Wright-Patterson AFB, OH 45433

597. Robert J. Russel1

17 Highgate Road

Framingham, MA 01701

598. L. Wiltiam Sahtey

Supermaterials Company

24400 Highland Road

Richmond Heights, OH 44143

599. Jon Salem

MASA Lewis Research Center

21000 Brookpark Center

Cleveland, $\mathrm{OH} 44135$

600. H. A. Sanders

MASA Lewis Research Center 21000 Brookpark Road, MS:49-3

Cleveland, OH 44135

601. J. Sankar

North Carolina A\&T State University

Department of Mechanical Engineering

Greensboro, MC 27411

602. Yasushi Sato

MGK Spark Plugs (U.S.A.), Inc. 1200 Business Center Drive, Suite 300

Mt. Prospect, IL 60056

603. Maxine L. Savitz

Allied-Signal Aerospace Company

Garrett Ceramic Components Division

19800 South Van Ness Avenue

Torrance, CA 90501

604. Ashok Saxena

Georgia Institute of Technology

Materials Engineering

Atlanta, GA 30332-0245 
605. David U. Scanion

Instron Corporation

100 Royall Street

Canton, MA 02021

606. Charles A. Schacht

Schacht Consulting Services

12 Holl and Road

Pittsburgh, PA 15235

607. James Schienle
Allied-Signal Aerospace
Company

Garrett Auxiliary Power

Division

2739 East Washington Street

P.0. Box 5227, MS:1302-2P

Phoenix, AZ 85010

608. John C. Schneider

San Juan Technologies

P.0. Box 49326

Colorado Springs, CO 80949-9326

609. Gary Schnittgrund

Rocketdyne, BA05

6633 Canoga Avenue

Canoga Park, CA 91303

610. Mark Schomp

Lonza, Inc.

Corporate Headquarters

17-17 Route 208

Fair Lann, NJ 07410

611. Joop Schoonman

Delft University of Technology

Laboratory for Inorganic Chemistry

P.0. Box 5045

2600 GA Delft

THE NETHERLANDS AIR MAIL

612. John Schuldies

Industrial Ceramic

Technology, Inc.

37 Enterprise Drive

Ann Arbor, MI 48103
613. Robert B. Schulz

U.S. Department of Energy

Office of Transportation

Materials

CE-34, Forrestal Building

Washington, DC 20585

614. Murray A. Schwartz

Materials Technology

Consulting, Inc.

30 Orchard Way, North

Potomac, MD 20854

615. Peter Schwarzkopf

SRI International

333 Ravenswood Avenue

Menlo Park, CA 94025

616. Thomas C. Schweizer

Princeton Economic Research, Inc.

12300 Twinbrook Pkwy., Suite 650

Rockville, MD 20852

617. Hillian T. Schwessinger

Multi-Arc Scientific

Coatings

1064 Chicago Road

Troy, MI 48083-4297

618. W. O. Scott

University of Washington

Materials Science Department

Mail Stop:FBIO

Seattle, WA 98195

619. Nancy Scoville

Thermo Electron Technologies

74 West Street

P.0. Box 9046

Haltham, MA 02254-9046

620. Brian Seegmiller

Coors Ceramics Company

600 9th Street

Golden, CO 80401 
621. T. B. Selover

AICRE/DIPPR

3575 Traver Road

Shaker Heights, OH 44122

622. J. H. Selverian

GTE Laboratories, Inc.

40 Sylvan Road

Waltham, MA 02254

623. Charles E. Semler

Semler Materials Services

4160 Mumford Court

Columbus, OH 43220

624. Thomas Service

Service Engineering Laboratory

324 Wells Street

Greenfield, MA 01301

625. Kish Seth

Ethyl Corporation

R\&D Laboratories

P.0. Box 341

Baton Rouge, LA 70821

626. Karleen Seybold

Allied-Signal Aerospace

Company

Garrett Auxiliary Power

Division

P.0. Box 5227

Phoenix, AZ 85010

627. William J. Shack

Argonne National Laboratory

9700 South Cass Avenue

Building 212

Argonne, IL 60439

628. Peter T. B. Shaffer

Technical Ceramics

Laboratories, Inc.

4045 Nine/McFarland Drive

Alpharetta, GA 30201

629. Richard K. Shaltens

MASA Lewis Research Center

21000 Brookpark Road,

MS:301-2

Clevel and, $\mathrm{OH} 44135$
630. Robert S. Shane

238 Hemlock Road

Uynnewood, PA 19096

631. Daniel Shanefield

Rutgers University

Ceramics Engineering Department

P.0. Box 909

Piscataway, NJ 08855-0909

632. Ravi Shankar

Chromalloy

Research and Technology Division

Blaisdell Road

Orangeburg, NY 10962

633. Terence Sheehan

Alpex theel Company

727 Berkley Street

New Milford, NJ 07646

634. Dinesh K. Shetty

University of Utah

304 EMRO, Dept. of Materials

Science and Engineering

Salt Lake City, UT 84112

635. Masahide Shimizu

Ceramic Society of Japan

2-2-503 Takiyama 6-chome

Higashikurume-Shi Tokyo 203

JAPAN AIR MAIL

636. John Shipinski

Toyota Technical Center U.S.A., Inc.

Technical Research Department 2000 Town Center, Suite $\mathbf{5 0 0}$

Southfield, MI 48075

637. Thomas Shreves

American Ceramic Society, Inc.

Library

757 Brooksedge Plaza Drive

Westerville, OH 43081-2821

638. Jack D. Sibold

Coors Ceramics Company

Contracts for Corporate Technology

4545 McIntyre Street

Golden, CO 80403 
639. George H. Siegel

Point North Associates, Inc.

P.0. Box 907

Madison, NJ 07940

640. Richard Silberglitt

Technology Assessment and Transfer, Inc.

133 Defense Highway, $\$ 212$

Annapolis, MD 21401

641. Mary Silverberg

Norton Company

Advanced Ceramics Library

Goddard Road

Northboro, MA 01532-1545

642. Gurpreet Singh

Department of the Navy

Internal Combustion \& Gas

Turbine Engine Division

Code 56x31

Washington, DC 20362-5101

643. Maurice J. Sinnott

University of Michigan

Chemical and Metallurgical Engineering

5106 IST Building

Ann Arbor, MI 48109-2099

644. John Skildum

3M Company

3M Center

Building 224-2S-25

St. PauT, MN 55144

645. David P. Smith

Hoskins, Rees \& Smith

1910 Cochran Road

Manor Oak II, Suite 658

Pittsburgh, PA 15220

646. Richard H. Smoak

Smoak \& Associates

3554 Hollyslope Road

Altadena, CA 91001-3923
647. Jay R. Smyth

Allied-Signal Aerospace Company

Garrett Auxiliary Power Division

2739 East Washington Street

P.0. Box 5227

MS: $93-173 / 1303-207$

Phoenix, AZ 85010

648. Edward A. Snajdr

Premier Refractories and Chemicals, Inc.

P.0. Box 392

Findlay, OH 44815

649. Rafal A. Sobotowski

British Petroleum Company

Technical Center, Broadway 3092 Broadway Avenue

Cleveland, $\mathrm{OH} 44115$

650. A. G. Solomah

SAC International Ltd.

1445 Bonhill Road, 13

Mississauga Ontario L5T $1 V 3$

CANADA AIR MAIL

651. S. Somiya

Nishi Tokyo University

3-7-19 Seijo, Setagaya

Tokyo 157

JAPAN AIR MAIL

652. Boyd W. Sorenson

DuPont Lanxide Composites

1300 Marrows Road

P.0. Box 6077

Neward, DE 19707

653. Charles A. Sorrell

U.S. Department of Energy

Advanced Industrial

Concepts Division

CE-232, Forrestal

Building

Washington, DC 20585 
654. C. Spencer

EA Technology

Capenhurst Chester CH1 6ES

UNITED KINGDOM AIR MAIL

655. Allen Spizzo

Hercules, Inc.

Hercules Plaza

Wilmington, DE 19894

656. Richard M. Spriggs

Alfred University

Center for Advanced Ceramic Technology

Alfred, NY 14802

657. Charles Spuckler

NASA Lewis Research Center

21000 Brookpark Road

MS: 5-11

Cleveland, OH 44135-3191

658. M. Srinivasan

Material Solutions

P.0. Box 663

Grand Island, NY 14702-0663

659. Gordon L. Starr

Cummins Engine Company, Inc.

Design \& Technology

P.0. Box 3005

Mail Code 50182

Columbus, IN 47202-3005

660. Jim Stevenson

Windrock, Incorporated

154 Fairbanks Plaza

Oak Ridge, TN 37830

661. Tom Stillwagon

Allied-Signal Aerospace

Company

Garrett Ceramic Components

Division

19800 South Van Ness Avenue

Torrance, CA 90501

662. Harold L. Stocker

General Motors Corporation Allison Gas Turbine Division P.0. Box 420 Indianapolis, IN 46206
663. Paul D. Stone

Dow Chemical USA

1776 "Eye" Street, N.H.,

Suite 575

Washington, DC 20006

664. Roger S. Storm

Carborundum Company

Technology Division

P.0. Box 337

Niagara Falls, NY 14302-0337

665. Peter A. Stranges

4 Chittenden Lane

Owings Mills, MD 21117

666. F. H. Stringer

Aero Industrial Technology Ltd.

P.0. Box 46, Wood Top

Burnley Lancashire BBII 4BX

UNITED KINGDOM AIR MAIL

667. Thomas N. Strom

MASA Lewis Research Center

21000 Brookpark Road

MS:86-6

Cleveland, OH 44135

668. M. F. Stroosnijder

Institute for Advanced

Materials

Joint Research Centre

21020 Ispra (VA)

ITALY AIR MAIL

669. Karsten Styhr

30604 Ganado Drive

Rancho Palos Verdes, CA 90274

670. T. S. Sudarshan

Materials Modification, Inc.

2929-PI Eskridge Center

Fairfax, VA 22031

671. M. J. Sundaresan

University of Miami

Mechanical Engineering Department

P.O. Box 248294

Coral Gables, FL 33124 
672. Patrick L. Sutton

U.S. Department of Energy

Advanced Propulsion Division CE-322, Forrestal Building Washington, DC 20585

673. Willard H. Sutton United Technologies

Corporation

Research Center, MS:24

Silver Lane

East Hartford, CT 06108

674. Ron Sviben

100 Indel Avenue

Rancocas, NJ 08073

675. J. J. Swab

U.S. Army Materials Technology Laboratory

Ceramics Research Division

SLCMT-EMC

405 Arsenal Street

Watertown, MA 02172

676. Robert E. Swanson

Metalworking Technology, Inc.

1450 Scalp Avenue

Johnstown, PA 15904

677. Scott L. Swartz

Battelie Columbus Laboratories

Metals and Ceramics

505 King Avenue

Columbus, $\mathrm{OH} 43201$

678. Steve Szaruga

Air Force Wright Aeronautical Laboratory

Materials Directorate

WL/MLBC

Wright-Patterson

$A F B, O H$ 45433-6533

679. Yo Tajima

NGK Spark Plug Company, Ltd.

NTK Technical Ceramic Division 2808 Iwasaki

Komaki-shi Aichi-ken 485

JAPAN AIR MAIL
680. Fred Teeter

5 Tralee Terrace

East Anherst, NY 14051

681. Monika O. Ten Eyck

Carborundum Company

Technology Division

P.0. Box 832

Niagara Falls, NY 14302

682. David F. Thompson

Corning 6lass Norks

SP-DV-02-1

Corning, NY 14831

683. Merle L. Thorpe

Hobart Tafa Technologies, Inc.

146 Pembroke Road

Concord, NH 03301

684. Eberhard Tiefenbacher

Daimler-Benz AG Abt. FIS

Mercedes-Strabe 136

Stuttgart 60

GERMANY AIR MAIL

685. T. Y. Tien

University of Michigan

Materials Science and

Engineering Department

Dow Buflding

Ann Arbor, MI 48103

686. Jutian M. Tishkoff

Air Force Office of Scientific Research

AFOSR/NA

Bolling AFB, DC 20332-6448

687. D. M. Tracey

Norton Company

Advanced Ceramics

Goddard Road

Northboro, MA 01532-1545

688. Dick Trippett

General Motors Corporation

Allison Gas Turbine Division

P.0. Box 420, MS:W-16

Indianapol is, IN 46206-0420 
689. L. J. Trostel, Jr. Box 199 Princeton, MA 01541

690. W. T. Tucker General Electric Company Corporate ReD Building KI-4C35 P.0. Box 8 Schenectady, NY 12301

691. Masanori Ueki Nippon Steel Corporation Central R\&D Bureau 1618 Ida Nakahara-Ku Kawasaki 211 JAPAN AIR MAIL

692. Filippo M. Ugolini

ATA Studio

Via Degli Sciptoni, 268A

ROMA 00192

ITALY AIR MAIL

693. Donald L. Vaccari

Allison Gas Turbines

P.0. Box 420

Speed Code 549

Indianapolis, IN 46206-0420

694. Carl F. Van Conant Boride Products, Inc. 2879 Aero Park Drive Traverse City, MI 49684

695. Marcel H. Van De Voorde Commission of the European Communities

Institute for Advanced Materials

Joint Research Centre

P.0. Box 2

1755 Z6 Petten

THE NETHERLANDS AIR MAIL

696. O. Van Der Biest

Katholieke Universiteit Leuven

Departement Metaalkunde en Toegepaste

de Croylaan 2

B-3030 Leuven

BELGIUA AIR MAIL
697. Michael Vannier

Washington University, St. Louis

Mallinckrodt Institute of Radiology

510 South Kings Highway

St. Louis, Mo 63110

698. Stan Venkatesan

Southern Coke \& Coal Corporation

P.0. Box 52383

Knoxville, TN 37950

699. V. Venkateswaran

Carborundum Company Niagara Falls RaD Center P.0. Box 832 Niagara Falls, NY 14302

700. Dennis Viechnicki

U.S. Army Materials Technology Laboratory

405 Arsenal Street

Watertown, MA 02172-0001

701. Ted Vojnovich

U.S. Department of Energy

Office of Energy Research, ER-42

Washington, DC 20585

702. John D. Volt

E. 1. Dupont de Nemours \& Company, Inc.

P.0. Box 80262

Wilmington, DE 19880

703. John B. Wachtman

Rutgers University

Ceramics Department

P.0. Box 909

Piscataway, NJ 08855

704. Shigetaka Mada

Toyota Central Research Labs, Inc.

Nagakute Aichi 480-11

JAPAN

AIR MAIL 
705. Janet Wade

Allied-Signal Aerospace Company

Garrett Auxiliary Power Division, Department 93-772

P.0. Box 5227, MS: 1303-2

Phoenix, AZ 85010

706. Richard L. Wagner

Ceramic Technologies, Inc.

537 Turtle Creek South Drive, Suite 240

Indianapolis, IN 46227

707. J. Bruce Wagner, Jr.

Arizona State University

Center for Solid State Science

Tempe, AZ 85287-1704

708. Daniel J. Wahten

Kohter, Co.

444 Highl and Drive

Kohler, WI 53044

709. Ingrid Wahlgren

Royal Institute of Technology

Studsvik Library

S-611 82 Nykoping

SHEDEN AIR MAIL

710. Ron H. Walecki

Allied-Signal Aerospace

Company

Garrett Ceramic Components

Division

19800 South Van Ness Avenue

Torrance, CA 90501

711. Michael S. Walsh

Vapor Technologies Inc.

2100 Central Avenue

Boulder, CO 80301

712. Chien-Min Wang

Industrial Technology Research Institute

Materials Research Laboratories

195 Chung-Hsing Road, Sec. 4

Chutung Hsinchu 31015 R.O.C.

TAIWAN AIR MAIL
713. Robert M. Washburn

ASNT

11203 Colima Road

Whittier, CA 90604

714. Gerald Q. Heaver

Carborundum Spectalty Products

42 Linus Allain Avenue

Gardner, MA 01440-2478

715. Karen E. Heber

Detroit Diesel Corporation

Technology and Planning

13400 West Outer Drive

Detroft, MI 48239-4001

716. R. H. Heeks

Argonne National Laboratory

MCT-212

9700 South Cass Avenue

Argonne, IL 60439

717. Ludwig Weiler

ASEA Brown Boveri AG

Corporate Research

Eppelheimer Str. 82

D-6900 Heidelberg

GERUANY

AIR MAIL

718. James Hessel

Dow Corning Corporation

1800 "M" Street, N.H.,

Suite 325 South

Washington, DC 20036

719. Robert D. West

Therm Advanced Ceramics

P.0. Box 220

Ithaca, NY 14851

720. Thomas J. Whalen

Ford Motor Company

26362 Harriet

Dearborn Heights, MI 48127

721. Ian A. White

Hoeganaes Corporation

River Road

Riverton, NJ 08077 
722. Alan Whitehead

General Electric Company

1 River Road, 55-111

Schenectady, NY 12345

723. Sheldon M. Wiederhorn National Institute of Standards and Technology Building 223, Room A329 Gaithersburg, ND 20899

724. John F. Wight Alfred University McMahon Building Alfred, NY 14802

725. D. S. Wilkinson McMaster University Materials Science and Engineering Department 1280 Main Street, Nest Hamilton Ontario L8S 4L7 CANADA AIR MAIL

726. James C. Williams General Electric Company Engineering Materials Technology Labs

One Neumann Way

Mail Drop: H85

Cincinnati, OH 45215-6301

727. Janette R. Williams Kollmorgen Corporation PCK Technology Division 150 Motor Parkway, 262 Hauppauge, NY 11788-5108

728. Steve J. Williams RCG Hagler Bailly, Inc. 1530 Wilson Boulevard, Suite 900

Arlington, VA 22209-2406

729. Craig A. Willkens

Norton Company

Advanced Ceramics Goddard Road Northboro, MA 01532-1545
730. Roger R. Wills TRW, Inc.

Valve Division

1455 East 185th Street

Cleveland, $\mathrm{OH} 44110$

731. David Gordon Wilson

Massachusetts Institute of Technology

Mechanical Engineering Department

77 Massachusetts Avenue, Room 3-455

Cambridge, MA 02139

732. Matthew F. Winkler Seaworthy Systems, Inc.

P.0. Box 965

Essex, CT 06426

733. Gerhard Winter

Hermann C. Starck Berlin GmbH, Werk Goslar

P.0. Box 2540

D-3380 Gosiar 3380

GERMANY AIR MAIL

734. W. L. Winterbottom

Ford Motor Company

Material Systems Reliability

Department

20000 Rotunda Drive

SRL, Room E-3182

P.0. Box 2053

Dearborn, MI 48121

735. David 6. Wirth

Coors Ceramics Company

600 9th Street

Golden, CO 80401

736. Thomas J. Wissing

Eaton Corporation

Engineering \& Research Center

P.0. Box 766

Southfield, MI 48037

737. James C. Withers

MER Corporation

7960 South Kolb Road

Building $F$

Tucson, AZ 85706 
738. Dale E. Wittmer

Southern Illinois University

Mechanical Engineering Department

Carbondale, IL 62901

739. Warren W. Wolf

Owens Corning Fiberglass

2790 Col umbus Road, Route 16

Granville, OH 43023

740. George W. Molter

Howmet Turbine Components

Corporation

Technical Center

699 Benston Road

Whitehall, MI 49461

741. James C. Nood

NASA Lewis Research Center

21000 Brookpark Road

MS:86-6

Cleveland, OH 44135

742. Marrill Nood

LECO Corporation

Augusta Division

P.0. Box 211688

Augusta, GA 30917-1688

743. Mayne L. Norrell

University of Pennsylvania

Department of Materials

Science and Engineering

3231 Halnut Street

Philadelphia, PA 19104

744. John F. Wosinski

Corning Inc.

ME-2 E-5 H8

Corning, NY 14830

745. Ian 6. Wright

Battelle Columbus Laboratories

$505 \mathrm{King}$ Avenue

Columbus, OH 43201

746. Ruth Wroe

ERDC

Metals \& Materials Industries Division

Capenhurst Chester CHI 6ES

ENGLAND

AIR MAIL
747. Bernard J. Wrona

Advanced Composite Materials

Corporation

1525 South Buncombe Road

Greer, SC 29651

748. Carl C. M. Mu

Maval Research Laboratory

Ceramic Branch, Code 6373

Washington, DC 20375

749. John C. Murst

University of Dayton Research Inst tute 300 College Park

Dayton, OH 45469-0101

750. Neil Wyant

ARCH Development Corp.

9700 South Cass Avenue

Building 202

Argonne, IL 60439

751. Roy Yamamoto

Texaco Inc.

P.O. Box 509

Beacon, NY 12508-0509

752. John Yamanis

Allied-Signal, Inc.

Ceramics Program

P.0. Box 1021

Morristown, W 07962-1021

753. Harry C. Yeh

Allied-Signal Aerospace

Company

Garrett Ceramic Components

Division

19800 South Van Ness Avenue

Torrance, CA 90509

754. Hiroshi Yokoyama

Hitachi Research Lab

4026 Kuji-Cho

Hitachi-shi Ibaraki 319-12

JAPAN AIR MAIL

755. Thomas M. Yonushonis

Cumins Engine Company, Inc.

P.0. Box 3005

Mail Code 50183

Columbus, IN 47202-3005 
756. Thomas J. Yost

Corning, Inc.

Technical Products Division, Main Plant 21-1-2

Corning, NY 14831

757. Jong Yung

Sundstrand Aviation Operations

Department 789-6

4747 Harrison Avenue

Rockford, IL 61125

758. A. L. Zadoks

Caterpillar Inc.

Technical Center, Building L

P.O. Box 1875

Peoria, IL 61656-1875

759. Avi Zangvil

University of Illinois

Materials Research Laboratory

104 South Goodwin Avenue

Urbana, IL 61801

760. Charles H. Zenuk

Transtech

6529 East Calle Cavalier

Tucson, AZ 85715

761. Anne Marie Zerega

U.S. Department of Energy

Office of Energy Research, ER-42

Washington, DC 20585

762. Ken Zillmer

Applied Test Systems, Inc.

2571 Mt. Gallant Road

Rock Hill, SC 29730

763. Carl Zweben

General Electric Company

P.0. Box 8555, VFSC/V4019

Philadelphia, PA 19101

764. Klaus M. Zwilsky

National Research Council

Mational Materials

Advisory Board

2101 Constitution Avenue

Washington, DC 20418
765. Department of Energy DOE Field Office, Oak Ridge Assistant Manager for Energy Research and Development P. 0. Box 2001

Oak Ridge, TN 37831-8501

766-775. Department of Energy

Office of Scientific and

Technical Information

Office of Information

Services

P.0. Box 62

Oak Ridge, TN 37831

For distribution by microfiche as shown in DOE/OSTI-4500, Distribution Category UC-332 (Ceramics/Advanced Materials). 